\title{
$111-4$
}

NASA Technical Memorandum 102769

AVSCOM Technical Report 90-B-012

\section{Mechanical Property Characterization and Impact Resistance of Selected Graphite/PEEK Composite Materials}

(NASA-TM-102759) MECHANICAL PROPEKTY

$N 91-24343$

CHAQACTRKIZATION AND IMPACT RESISTANCE DF

SELFCTED GKAPHITE/PEEK COMPOSITE MATERIALS

(NASA) $30 \mathrm{p}$

$\operatorname{CSCL} 11 \mathrm{n}$

$63 / 24 \quad \begin{array}{ll}\text { Unclas } \\ 0013480\end{array}$

Donald J. Baker

April 1991

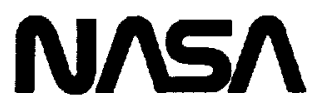

National Aeronautics and Space Administration

Langley Research Center Hampton, Virginia 23665

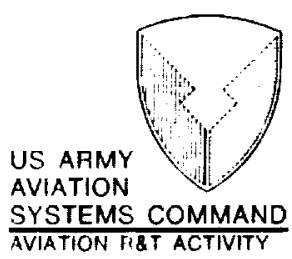


$y$ 


\title{
MECHANICAL PROPERTY CHARACTERIZATION \\ and \\ IMPACT RESISTANCE \\ of \\ SELECTED GRAPHITE/PEEK COMPOSITE MATERIALS
}

\author{
by \\ Donald J. Baker \\ Aerostructures Directorate \\ U.S.Army Research and Technology Activity(AVSCOM) \\ Langley Research Center \\ Hampton, VA 23665-5225
}

\begin{abstract}
To use graphite/PEEK material on highly curved surfaces requires that the material be drapable and easily conformable to the surface. This paper presents the mechanical property characterization and impact resistance results for laminates made from two types of graphite/PEEK materials that will conform to a curved surface. These laminates were made from two different material forms. These forms are: 1.) a fabric where each yarn is a co-mingled Celion G30-500 3K graphite fiber and PEEK thermoplastic fiber; and 2.) an interleaved material of Celion G30-500 3K graphite fabric interleaved with PEEK thermoplastic film. The experimental results from the fabric laminates are compared with results for laminates made from AS4/PEEK unidirectional tape. The results indicate that the tension and compression moduli for quasi-isotropic and orthotropic laminates made from fabric materials are at least 98 percent of the modulus of equivalent laminates made from tape material. The strength of fabric material laminates is at least 80 percent of laminates made from tape material. The evaluation of the fabric material for shear stiffness indicates that a tape material laminate could be replaced by a fabric material laminate and still maintain 89 percent of the shear stiffness of the tape material laminate. The notched quasi-isotropic compression panel failure strength is $\mathbf{4 2}$ to 46 percent of the unnotched quasi-isotropic laminate strength. Damage area after impact with $20 \mathrm{ft}-\mathrm{lbs}$ of impact energy is larger for the co-mingled panels than for the interleaved panels. The interleaved panels have less damage than panels made from tape material. Residual compression strength of quasi-isotropic panels after impact of $20 \mathrm{ft}$-lbs of energy varies between 33 percent of the
\end{abstract}


undamaged quasi-isotropic material strength for the tape material and 38 percent of the undamaged quasi-isotropic material strength for the co-mingled fabric material.

\section{INTRODUCTION}

The lack of tack and drapability of unidirectional graphite/polyetheretherketone (PEEK) prepreg tape makes it difficult to use on highly curved surfaces. To use graphite/PEEK material on curved surfaces requires that the material be drapable and conform easily to the surface. A fabric material that has not been impregnated with resin will conform to curved surfaces better than unidirectional prepreg tape. A tow material is available that is made by co-mingling Celion G30-500 3K graphite fibers and PEEK thermoplastic fibers. This co-mingled tow can be woven into a fabric which can be handled in a manner that is similar to dry graphite fabric of the same weave style. Once this co-mingled fabric is placed on a curved surface, only heat and pressure are necessary to consolidate the laminate. Another method of manufacturing thermoplastic parts that have curved surfaces is to interleave dry graphite fabric and thermoplastic film. This method of interleaving graphite fabric and thermoplastic film provides the flexibility necessary for forming a fabric to a curved surface but the resin must infiltrate the graphite tows at the time of consolidation.

This paper presents experimental results of a study to characterize the mechanical properties of unidirectional, orthotropic, and quasi-isotropic laminates made of graphite/PEEK material subjected to tension, compression, and shear loads. The compression strength of notched quasi-isotropic laminates and the compression-after-impact residual strength of quasiisotropic laminates are also presented. All laminates are graphite/PEEK material that has been fabricated from AS-4/PEEK unidirectional prepreg tape or from graphite fabrics and PEEK resin that were fabricated by two methods. The purpose of this paper is to compare the properties of the laminates made from fabrics using two different fabrication techniques with the properties of laminates made from unidirectional graphite/PEEK prepreg tape.

The use of trademarks or names of manufactures in this paper is for accurate reporting and does not constitute an official endorsement, either expressed or implied, of such products or manufacturers by the National Aeronautics and Space Administration or the U.S. Army Research and Technology Activity.

\section{MATERIALS}

The graphite/PEEK material used in this study was purchased as 17 -inch-long by 17 -inchwide by 0.25 -inch-thick laminates. Laminates of three different types of graphite/PEEK materials were obtained for evaluation in this study. The laminates were fabricated from the following materials: 1.) AS-4 graphite/APC-2 2 PEEK unidirectional preimpregnated tape; 2.) co-mingled tows of Celion G30-500 $3 \mathrm{~K}^{3}$ graphite fibers and grade $150 \mathrm{~g}$ PEEK fibers, woven into an 8-harness satin weave fabric with 18 yarns per inch in both the warp and fill directions,

1. Hercules. Inc. Magna, UT.

2. ICI Advanced Malcrials, Tempe AZ.

3. BASF Fibers, Charlote, NC. 
and will be referred to as a co-mingled fabric in the paper; and 3.) graphite fabric interleaved with 5-mil-thick grade $450 \mathrm{~g}$ PEEK film ${ }^{4}$. The fabric is an 8-hamess satin we ave of Celion G30$5003 \mathrm{~K}$ graphite fibers with 18 yarns per inch in both the warp and fill direction. This material is referred to as film-stacked fabric in the paper. The PEEK resins APC-2, grade $150 \mathrm{~g}$ and $450 \mathrm{~g}$ have subtle differences in the molecular weights and molecular weight distribution which have some effect on the processability of the resins. Laminates with the unidirectional prepreg tape and co-mingled tows were specified to have a fiber volume fraction of $60 \pm 3$ percent. The laminates with the interleaved film were specified to have a fiber volume fraction of $60 \pm 5$ percent. The tape material was layed-up in the following orientations: 1.$)[45 / 0 /-45 / 90]_{6 s} ; 2$.) $[0 / 90]_{12 s}$; and 3.) [0] $48^{\circ}$ The fabric material was layed-up in the following orientations: 1.) $[45 \mathrm{~F} / 0 \mathrm{~F}]_{6 \mathrm{~s}}$ and 2.) $\left[0 \mathrm{~F}_{24}\right.$. The $[45 / 0 /-45 / 90]$ laminates for tape and the $[45 \mathrm{~F} / 0 \mathrm{~F}] 6 \mathrm{~s}$ laminates for fabric wifl be identified as quasi-isotropic laminates. The $[0 / 90]_{12}$ laminate for tape and the $[0 \mathrm{~F}]_{24}$

laminate for fabrics will be identified as orthotropic laminates. The [0] ${ }_{48}$ laminate is identified as a unidirectional tape laminate.

At the time these laminates were procured, it was not possible to obtain the same fiber in both the unidirectional tape and the co-mingled tow form. The two fibers selected have similar material properties as shown in Table 1. The values shown for AS-4 fibers are typical properties from the manufacture's literature (reference 1) while the properties shown for the Celion fiber are the actual certification values for the fibers used in the laminates. The Celion G30-500 fiber modulus is 3.0 percent higher than the AS-4 fiber modulus as shown in Table 1 . The Celion G30-500 fiber has approximately 7.0 percent higher strength and 0.16 percent higher elongation than the AS -4 fiber.

\section{TEST SPECIMENS}

The laminates were machined into specimens as shown in figures 1 and 2 . The tension specimen shown in figure 1 is similar to but thicker than the specimen recommended by ASTM D-3039 and the specimens were not tabbed. The tension specimen for unidirectional tape was machined to be $0.5 \mathrm{in}$. wide and only back-to-back axial strain gages were used to measure strains. The compression specimen, shown in figure 1 , is a configuration that has been used by NASA-Langley Research Center for other material evaluations (reference 2). The tension and compression specimens were cut from the same panel to eliminate panel-to-panel variability. The configuration of the Iosipescu shear specimen is given in reference 3 . Although the Iosipescu shear specimen is not an ASTM accepted specimen, it was used for two reasons; namely, material conservation and ease of testing. Also, the results can be used to compare the shear moduli of the different materials. Configurations for the compression-after-impact and notched compression panels are shown in figure 2 and are similar to the panels described in reference 4. Replicate specimens, as noted below, were tested in order to obtain average values for each engineering property. Strain gages were installed at locations shown in figures 1 and 2 .

4. Westlake Plastics Co., I enni, PA. 


\section{TEST PROCEDURES}

All tests were performed at room temperature in the as-fabricated condition. No environmental conditioning was performed on any specimen. The load, strain and test machine head displacement were recorded every two seconds with a computer controlled data acquisition system.

Tension - All tests were performed on untabbed specimens in a 55 kip hydraulic test machine with hydraulic grips. A 6.0-in.-long test section was used for all tension tests. All specimens were tested to failure. The loading rate was 8000 pounds per minute. Unless otherwise indicated three replicates of each specimen were tested.

Compression - All tests were performed using the fixture shown in figure 3. The specimens were tested to failure in a 100 or a 120 kip hydraulic test machine. The specimens were loaded at a rate of $\mathbf{8 0 0 0}$ pounds per minute. Unless otherwise indicated four replicates of each specimen were tested.

Shear - All tests were performed using the test fixture for the Iosipescu shear specimen shown in figure 4. The specimens were tested in a displacement controlled test machine and were loaded at a crosshead displacement rate of 0.01 inches per minute. Only the transverse test specimens of unidirectional tape were failed. Loading on the other specimens was stopped when equipment limits were reached or crushing was observed at the loading surface. Unless otherwise indicated four replicates of each specimen were tested.

Compression Panels - The notched compression and compression-after-impact tests of laminates were performed in the fixture shown in figure 5. The specimens were tested to failure in a 120 or a $300 \mathrm{kip}$ hydraulic test machine. The specimens were loaded at the rate of 8000 pounds per minute until failure. Unless otherwise noted three replicates of each specimen were tested.

Specimens to be impacted were installed into the fixture shown in figure 5 and impacted with a low-velocity air gun apparatus. The gun fires 0.50 -inch-diameter aluminum spheres with a mass of $0.0065 \mathrm{lb}$. at a selected velocity. A velocity of $443 \mathrm{ft} / \mathrm{sec}$ is required to achieve an impact energy of $20 \mathrm{ft}-\mathrm{lb}$. After impact the test panels were ultrasonically inspected to provide a measure of the impact damage area. The impacted laminates were tested to failure by the same procedure as the notched laminates. Unless otherwise indicated three replicates of each specimen were tested.

\section{RESULTS and DISCUSSION}

Photomicrographs and fiber volume fraction measurements were taken of all the laminates. Typical photomicrographs of the $[0 \mathrm{~F}]_{24}$ co-mingled and film-stacked fabric laminates are shown in figures 6 and 7 , respectively. The co-mingled fabric, shown in figure 6 , has some voids in the resin rich areas where the crimp in the fibers in adjacent plies approach each other. Good resin infiltration through the fibers is indicated. The photomicrograph of the film-stacked laminate (figure 7) indicates excess resin between each fabric layer, where the film of thermoplastic material is inserted in the stacking sequence. The photomicrographs show good resin infiltration 
through the fibers. Photomicrographs of the laminates made from the unidirectional prepreg tape (figure 8) indicate good fiber and icsin distribution with no resin rich areas or voids.

Representative samples were removed from the laminates for fiber volume fraction determination. The samples were digested in concentrated sulfuric acid and hydrogen peroxide according to ASTM D-3171 procedures to determine the fiber weight percent. The fiber volumes for each material are shown in Table 2. The fiber volumes vary between 58.6 percent for the film-stacked material and 62.7 percent for the orthotropic tape material. All the fiber volume fractions shown in Table 2 are within the requirements of $60 \pm 5$ percent for the filmstacked laminates and $60 \pm 3$ percent for the other laminates.

Tension properties - The average values for ultimate strength, Young's modulus, Poisson's ratio, and maximum strain from laminate tension tests are listed in Table 3. The ultimate strength and moduli results of the quasi-isotropic laminates are shown in figures 9 and 10. These figures also include a bar which indicates the range of failure strengths for each series of tests. The comingled fabric laminates had the maximum variation in strength in the longitudinal direction of 7 $\mathrm{ksi}$, or 8 percent, of the average longintudinal strength. The laminate made from tape has an average transverse strength that is approximately $16 \mathrm{ksi}$, or 18 percent, higher than the average longitudinal strength. There is no obvious reason for this difference. A possible explanation for this increased strength is that the first fiber that is parallel to the load direction is deeper in the laminate for the transverse load case than for the longitudinal load case which creates a different load path for shearing the load into the load bearing fibers of the laminate. The average strengths in each direction (longitudinal or transverse) for the film-stacked and co-mingled material are within $11 \mathrm{ksi}$ of each other. The average longitudinal strength of $77.5 \mathrm{ksi}$ for the film-stacked material is approximately $9 \mathrm{ksi}$ iower than that of the co-mingled material. The tension strength of the fabrics is 79 to 88 percent of the tape strength. This tensile strength reduction is typical of specimens of woven fabric with crimped fibers in the loading direction when compared to tape material with straight fibers in the loading direction. The tape laminates have a higher failure strain of 1.31 to 1.50 percent than the fabric laminates which failed at 1.16 to 1.27 percent strain. The average moduli values for the quasi-isotropic material are shown in figure 10. All modulus values in Table 3 were determined by performing a linear least squares fit of the data between 0 and $25 \mathrm{ksi}$ (approximately 0.3 percent strain). The bar graphs that do not show a data range have a variation so small that it could not be shown on the graph. The maximum data scatter for the moduli (figure 10) is $0.48 \mathrm{msi}$, or 7 percent, for the longitudinal modulus of the tape material. The moduli in the longitudinal and transverse directions are nearly equal (within $0.25 \mathrm{msi}$ ) to each other as they should be for a quasi-isotropic laminates. The average moduli for fabric materials are 104 percent of the modulus of the tape material. A typical stress-strain curve for the quasi-isotropic laminates of each material form is shown in figure 11. The curves for all laminates are bi-linear. The knee of each curve occurs at approximately $30 \mathrm{ksi}$.

The average ultimate tension strength and Young's modulus for orthotropic laminates are also given in Table 3 and shown in figures 12 and 13. The maximum scatter in the strength data for the longitudinal direction of the tape laminates is $13 \mathrm{ksi}$, or 13 percent, of the longitudinal strength. The difference between the longitudinal and transverse strength is $7 \mathrm{ksi}$ for the tape 
laminates. The average strength (longitudinal and transverse) for the tape laminate is $97 \mathrm{ksi}$. Laminates made from film-stacked fabrics have less than $1 \mathrm{ksi}$, or 1 percent, difference between the average longitudinal and transverse strengths. The co-mingled fabrics have less than $5 \mathrm{ksi}$, or 5 percent, difference between the average longitudinal and transverse strengths. The average strength for the co-mingled fabric is approximately $10 \mathrm{ksi}$ higher than the average strength of the film-stacked fabric laminates. The average strength of the film-stacked laminate is 98 percent of the tape material strength and the co-mingled material average strength is 110 percent of the tape material strength. Failure strain for the fabric materials ranges from 0.95 to 1.12 percent strain. The longitudinal modulus for the orthotropic tape laminates is approximately $1.0 \mathrm{msi}$, or 10 percent, higher than the transverse modulus and has very little scatter. The moduli shown for all orthotropic fabric laminates are within $0.4 \mathrm{msi}$, or 4 percent, of one another as shown in figure 13 and Table 3. These moduli have very little scatter. The moduli are approximately equal in each direction as expected for the layup. The average moduli for the film-stacked and co-mingled materials are 97 and 94 percent, respectively, of the modulus of the tape material. All moduli values were determine by performing a linear least squares fit of the data between 0 and $25 \mathrm{ksi}$ (approximately 0.3 percent strain). Typical stress-strain curves for orthotropic laminates are shown in figure 14. The curves for all laminates are linear to failure.

The Young's modulus of $19.55 \mathrm{msi}$ for unidirectional tape (Table 3) is reasonable for the 33-msi-modulus AS-4 fiber and the 61.9 percent fiber volume noted earlier. Realistic tension strength values for the unidirectional tape material could not be obtained since the specimens were not tabbed and end failures occurred.

The above results indicate that a quasi-isotropic laminate of fabric material, either comingled or film-stacked, could replace a quasi-isotropic laminate of tape material in a tension application with a 4 percent increase in stiffness and with approximately 80 percent of the tape strength. A orthotropic laminate of fabric material, either co-mingled or film-stacked, could replace an orthotropic tape laminate in a tension application with a 98 percent stiffness retention and 94 percent strength retention.

Compression properties - Average ultimate compression strength, Young's modulus, Poisson's ratio and strain at failure from the compression tests are listed in Table 4. The ultimate strength and moduli data from the quasi-isotropic laminates are also shown in figures 15 and 16. These figures show the range of data for each test condition. The range of data for strength (figure 15) is highest for the film-stacked laminate which has differences between maximum and minimum strengths of $38.6 \mathrm{ksi}$, or 46 percent, for the longitudinal direction and $21.3 \mathrm{ksi}$, or 25 percent, for the transverse direction. The reason for these large variances is not apparent since all specimens were machined from the same laminate and the nondestructive evaluation did not reveal any anomalities in the laminates. The laminate made from tape has a transverse strength that is $7 \mathrm{ksi}$, or 7 percent, higher than the longitudinal strength. This trend is the same as that for the tension strength. The average longitudinal strength of the film-stacked fabric is $83 \mathrm{ksi}$ while the average longitudinal strength for the co-mingled fabric is $84.3 \mathrm{ksi}$. The transverse strengths for the fabrics is within $3.4 \mathrm{ksi}$, or 4 percent, of the longitudinal strength. The average strength (longitudinal and transverse) for the fabrics is within 87 percent of the tape material. The tape 
laminates have higher failure strains of 1.31 to 1.50 percent, than the fabric laminates which failed at strains between 1.16 to 1.27 percent. The average moduli values shown in figure 16 for the quasi-isotropic tape and fabric materials are within $0.25 \mathrm{msi}$, or 4 percent, of each other. The maximum data scatter in the moduli (figure 15) is $0.37 \mathrm{msi}$, or 6 percent, for tape material in the longitudinal direction. The moduli in each direction are nearly equal (within $0.21 \mathrm{msi}$ ) to each other as they should be for a quasi-isotropic material. The average moduli for the fabric materials are within 2.0 percent of the 6.63 msi for the tape material. All modulus values in Table 4 were determined by performing a linear least squares fit of the data between 0 and $25 \mathrm{ksi}$ (approximately 0.4 percent strain). A typical compression stress-strain curve for the quasiisotropic material is shown in figure 17. The curves are linear to approximately $25 \mathrm{ksi}$ and then exhibit a constantly changing slope to failure.

Ultimate strength and moduli data for orthotropic laminates are shown in figures 18 and 19. The data scatter for strength (figure 18) is the highest for the film-stacked fabric with differences between maximum and minimum strengths of $22 \mathrm{ksi}$, or 31 percent, for the longitudinal direction and $27.1 \mathrm{ksi}$, or 38 percent, for the transverse direction. Average strengths of the orthotropic fabric laminates are nearly equal in each direction as expected for a laminate which has the same number of yams in the warp and fill directions. The average strength for the fabrics vary between 93 and 114 percent of the strength of laminates fabricated from tape material. The failure strains for the tape and fabric materials varies between 0.80 and 1.03 percent. The average moduli shown in figure 19 for the tape and fabric materials are within 0.31 msi, or 3 percent, of each other. The maximum data scatter in the modulus (figure 19) for tape material in the transverse direction is $1.49 \mathrm{msi}$, or 17 percent. The average moduli for each material in each direction are nearly equal (within $0.27 \mathrm{msi}$ ) to each other. The average moduli for the fabric materials are within 1.0 percent of the 8.95 msi modulus of the tape material. All modulus values in Table 4 were determined by performing a linear least squares fit of the data between 0 and $25 \mathrm{ksi}$ (approximately 0.4 percent strain). A stress-strain curve for the orthotropic laminates of each material form is shown in figure 20 . The curves are linear to $25 \mathrm{ksi}$ then have a constantly changing slope to failure.

The compression modulus of $17.62 \mathrm{msi}$ (Table 4) for unidirectional tape is reasonable for the 33-msi-modulus of the AS-4 fiber and the 61.9 percent fiber volume noted earlier. No strength values are given for tape material in the longitudinal direction because all tests failed by end failures.

The above discussion indicates that a quasi-isotropic laminate of fabric material, either comingled or film-stacked, could replace a quasi-isotropic tape laminate in a compression application with a 98 percent stiffness retention and 87 percent strength retention. An orthotropic laminate of fabric material, either co-mingled or film-stacked, could replace an orthotropic tape laminate with 99 percent stiffness retention and 93 percent strength retention.

Shear properties - The average values from all tests for the shear moduli are given in Table 5 . Moduli for the quasi-isotropic laminates are also shown in figure 21. Typical stress-strain curves for the quasi-isotropic laminates are shown in figure 22. Comparison of the curves in figure 22 indicates the film-stacked and co-mingled materials are nearly linear while the tape material has a 
constantly changing slope. The moduli values for the film-stacked and co-mingled materials shown in figure 21 were determined by a linear least square fit of the data to approximately 1.5 percent strain. Modulus values shown for the tape material are the initial value. Also shown in Table 5 are secant modulus values for the tape material which is the slope of a line between initial strain and 1.5 percent strain. The secant modulus for the fabric materials would be the same as the Young's Modulus. The average secant modulus for the fabric is $\mathbf{9 2}$ percent of the average modulus of the tape materials. The transverse and longitudinal moduli for fabric materials, shown in figure 21 , are within $0.10 \mathrm{msi}$, or 4 percent, of each other for each type of laminated material as they should be for a quasi-isotropic material.

Young's moduli values for the orthotropic laminates are given in Table 5 and are shown in figure 23. Typical stress-strain curves for the orthotropic laminates are shown in figure 24. All of the curves shown in figure 24 have a constantly changing slope. Moduli shown in Table 5 include an initial slope (Young's Modulus) and the secant modulus between initial strain and 1.5 percent strain. All of the materials exhibit a higher secant modulus in the longitudinal direction than in the transverse direction with the tape material having the highest modulus at $0.70 \mathrm{msi}$, while the modulus in the transverse direction is $0.58 \mathrm{msi}$. The average secant modulus for the fabric material is $0.57 \mathrm{msi}$ and is 89 percent of the average moduli of the tape material.

Only the unidirectional tape specimens tested in the transverse direction failed. Their average strength is $14.9 \mathrm{ksi}$.

The evaluation of the material for shear stiffness indicates that the tape material could be replaced by the fabric materials for a quasi-isotropic laminate with a 92 percent retention of shear stiffness. For an orthotropic application the fabric laminates would have a shear stiffness of 89 percent of the tape laminates.

Notched compression strength - Results of compression tests on quasi-isotropic panels with 1.0in.-diameter central hole are presented in Table 6 and shown in figure 25. These strength values are the average of three tests for the tape and co-mingled materials and the average of two tests for the film-stacked material. All stress values are the far field stress values. The range of test values are also shown in figure 25 . The strength of the notched tape specimens have the lowest values of all material forms with 42 percent of the unnotched laminate compression strength (Table 4), while the strength of the film-stacked fabric is the highest with 46 percent of the unnotched laminate strength.

Compression-after-impact strength - Results of the compression-after-impact tests are presented in Table 7 and shown figure 25. The impact energy, damage area, and residual strength are given for each specimen tested. All stress values are the far field stress values. All panels, except one, were impacted at 19.7 to $20.8 \mathrm{ft}-\mathrm{lbs}$ of energy. The film-stacked panel impacted at $10.9 \mathrm{ft}-\mathrm{lbs}$ of energy had a smaller damage area than the panels impacted with a higher energy level. This panel also had a residual strength of 86 percent of the panels impacted with a higher energy level. The average damage area for an impact energy of $20 \mathrm{ft}$-lbs was the lowest for the film-stacked panels with a damage area of 2.52 sq. in. (Table 7). This material form has the highest residual strength with 46 percent of the undamaged material strength. The co-mingled laminates have a damage area of $3.14 \mathrm{sq}$. in. and a residual strength of 38 percent of the undamaged material 
strength. The tape laminates have a damage area of $2.77 \mathrm{sq}$. in. and the lowest residual strength of the material forms with 33 percent of the undamaged material strength. The tape and comingled panels have lower residual strengths after $20 \mathrm{ft}-\mathrm{lb}$ of impact damage than panels with a 1.0-inch-diameter hole while the residual strength of the impact damaged film-stacked panel is higher than panels with a 1.0-in.-diameter hole.

\section{CONCLUDING REMARKS}

Three types of graphite/PEEK laminates were tested to obtain tension, compression and shear mechanical properties. The laminates were fabricated from three different forms of graphite/thermoplastic material: AS4/PEEK unidirectional tape; fabric where each yarn was comingled Celion G30-500 3K graphite tow and PEEK thermoplastic fibers; and Celion G30-500 3K graphite fabric interleaved with PEEK thermoplastic film (also called film-stacked). In addition, compression properties were generated for notched quasi-isotropic laminates. Quasiisotropic compression panels were impacted and residual compression strengths were determined.

The results of the tests indicate that a quasi-isotropic laminate of fabric material, either comingled or film-stacked, could replace a quasi-isotropic laminate of tape material in a tension application with a 4 percent increase in stiffness and with approximately 80 percent of the tape strength. An orthotropic laminate of fabric material, either co-mingled or film-stacked, could replace an orthotropic tape laminate in a tension application with a 98 percent stiffness retention and 94 percent strength retention.

The results of the tests indicate that a quasi-isotropic laminate of fabric material, either comingled or film-stacked, could replace a quasi-isotropic tape laminate in a compression application with a 98 percent stiffness retention and 87 percent strength retention. An orthotropic laminate of fabric material, either co-mingled or film-stacked, could replace an orthotropic tape laminate in a compression application with 99 percent stiffness retention and 93 percent strength retention.

The evaluation of the material for shear stiffness indicates that the tape material could be replaced by the fabric materials for a quasi-isotropic laminate with a 92 percent retention of shear stiffness. For an orthotropic application the fabric laminates would have a shear stiffness of 89 percent of the tape laminates.

The results indicated that the failure strength for the notched compression panels was 42 to 46 percent of the unnotched laminate strength. The results also indicated that after an impact of $20 \mathrm{ft}-\mathrm{lbs}$, the damage area was largest for the co-mingled panels and smallest for the film-stacked panels. Damage area in the tape panels was in between the damage areas of the fabric panels. The residual strength after impact varied between 33 percent of the laminate strength for tape material and 38 percent of the laminate strength for the co-mingled fabric material. 


\section{REFERENCES}

1. Anon.: Manufacture's data on AS-4 graphite fiber. Hercules Composite Products Group, Baccus Works, Magna, UT, February, 1989.

2. Dow, Marvin B.; and Smith, Donald L.: Properties of Two Composite Materials Made of Toughened Epoxy Resin and High-Strain graphite Fiber. NASA TP-2826, July 1988.

3. Walrath, David E.; and Adams, Donald F.: Iosipescu Shear Properties of Graphite Fabric/Epoxy Composite Laminates. NASA CR-176316, June 1985.

4. ACEE Composites Project Office, compiler: Standard Tests for Toughened Resin CompositesRevised Edition. NASA RP-1092, 1983. (Supersedes NASA RP-1092, 1982) 
Table 1

Fiber properties

\begin{tabular}{lcc}
\hline \multirow{2}{*}{$\begin{array}{c}\text { Material } \\
\text { Property }\end{array}$} & \multicolumn{2}{c}{ Material } \\
\cline { 2 - 3 } & $\begin{array}{c}\text { Hercules } \\
\text { AS-4 }\end{array}$ & $\begin{array}{c}\text { Celion } \\
\text { G30-500 3K }\end{array}$ \\
\hline Modulus, msi & 33 & 33.9 \\
Strength, ksi & 580 & 596 \\
Elongation, \% & 1.6 & 1.76 \\
Specific Gravity & 1.79 & 1.79 \\
\hline \hline
\end{tabular}

Table 2

Fiber volume

\begin{tabular}{|c|c|}
\hline Material & $\begin{array}{c}\text { Fiber Volume, } \\
\text { percent }\end{array}$ \\
\hline \multicolumn{2}{|c|}{ Tape } \\
\hline$[0]_{48}$ & 61.9 \\
\hline$[0 / 90]_{12 \mathrm{~s}}$ & 62.7 \\
\hline$[45 / 0 /-45 / 90]_{6 s}$ & 60.3 \\
\hline \multicolumn{2}{|c|}{ Co-mingled Fabric } \\
\hline$[\mathrm{OF}]_{24}$ & 59.6 \\
\hline$[45 \mathrm{~F} / 0 \mathrm{~F}]_{6 \mathrm{~s}}$ & 60.3 \\
\hline \multicolumn{2}{|c|}{ Film-Stacked Fabric } \\
\hline$[\mathrm{OF}]_{24}$ & 58.8 \\
\hline$[45 \mathrm{~F} / 0 \mathrm{~F}]_{6 \mathrm{~s}}$ & 58.6 \\
\hline
\end{tabular}


Table 3

Average tensile properties of graphite/PEEK laminates

\begin{tabular}{|c|c|c|c|c|c|}
\hline $\begin{array}{c}\text { Laminate } \\
\text { Type }\end{array}$ & $\begin{array}{c}\text { Direction } \\
\text { (a) }\end{array}$ & $\begin{array}{c}\text { Strength, } \\
\text { ksl }\end{array}$ & $\begin{array}{c}\text { Modulus, } \\
\text { msi }\end{array}$ & $\begin{array}{c}\begin{array}{c}\text { Poisson's } \\
\text { Ratio }\end{array} \\
\end{array}$ & $\begin{array}{l}\text { Maximum } \\
\text { Strain,\% } \\
\end{array}$ \\
\hline \multicolumn{6}{|c|}{ Quasi-isotropic } \\
\hline $\begin{array}{l}\text { Tape } \\
{[45 / 0 /-45 / 90]_{6 s}}\end{array}$ & $\stackrel{L}{T}$ & $\begin{array}{r}88.2 \\
104.6\end{array}$ & $\begin{array}{l}6.73 \\
6.82\end{array}$ & $\begin{array}{l}0.303 \\
0.305\end{array}$ & $\begin{array}{l}1.31 \\
1.50\end{array}$ \\
\hline $\begin{array}{l}\text { Fabric } \\
\text { film-stacked } \\
{[45 \mathrm{~F} / 0 \mathrm{~F}]_{6 s}}\end{array}$ & L & $\begin{array}{l}77.5 \\
88.2\end{array}$ & $\begin{array}{l}6.93 \\
7.10\end{array}$ & $\begin{array}{l}0.303 \\
0.298\end{array}$ & $\begin{array}{l}1.16 \\
1.18\end{array}$ \\
\hline$\underset{[45 \mathrm{~F} / 0 \mathrm{~F}]_{6 s}}{c o-m i n g l e d}$ & $\stackrel{L}{T}$ & $\begin{array}{l}86.7 \\
83.1\end{array}$ & $\begin{array}{l}7.03 \\
6.98\end{array}$ & $\begin{array}{l}0.314 \\
0.305\end{array}$ & $\begin{array}{l}1.27 \\
1.23\end{array}$ \\
\hline $\begin{array}{l}\text { Tape } \\
{[0]_{48}}\end{array}$ & L & $\begin{array}{l}\text { Unidirect } \\
\text { (b) } \\
\text { Orthotro }\end{array}$ & 19.55 & (c) & (b) \\
\hline $\begin{array}{l}\text { Tape } \\
{[0 / 90]_{12 s}}\end{array}$ & L & $\begin{array}{l}100.6 \\
93.4\end{array}$ & $\begin{array}{l}10.60 \\
9.71\end{array}$ & $\begin{array}{l}0.022 \\
0.029\end{array}$ & $\begin{array}{l}0.98 \\
0.94\end{array}$ \\
\hline $\begin{array}{l}\text { Fabric } \\
\text { film-stacked } \\
{[0 \mathrm{~F}]_{12 s}}\end{array}$ & L & $\begin{array}{l}95.4 \\
94.6\end{array}$ & $\begin{array}{l}9.74 \\
9.99\end{array}$ & $\begin{array}{l}0.038 \\
0.039\end{array}$ & $\begin{array}{l}0.98 \\
0.95\end{array}$ \\
\hline $\begin{array}{l}\text { co-mingled } \\
{[\mathrm{OF}]_{12 s}}\end{array}$ & $\frac{L}{T}$ & $\begin{array}{l}109.0 \\
104.7\end{array}$ & $\begin{array}{l}9.47 \\
9.64\end{array}$ & $\begin{array}{l}0.044 \\
0.041\end{array}$ & $\begin{array}{l}1.12 \\
1.08\end{array}$ \\
\hline
\end{tabular}
(a) L - Longintudinal Direction
$T$ - Transverse Direction
(b) End failures
(c) Not available 
Table 4

Average compression properties of graphite/PEEK laminates

\begin{tabular}{|c|c|c|c|c|c|}
\hline $\begin{array}{l}\text { Laminate } \\
\text { Type }\end{array}$ & $\begin{array}{l}\text { Direction } \\
\text { (a) }\end{array}$ & $\begin{array}{c}\text { Strength, } \\
\text { ksi }\end{array}$ & $\begin{array}{c}\text { Modulus, } \\
\text { msi }\end{array}$ & $\begin{array}{c}\begin{array}{c}\text { Poisson's } \\
\text { Ratio }\end{array} \\
\end{array}$ & $\begin{array}{l}\text { Maximum } \\
\text { Strain,\% }\end{array}$ \\
\hline \multicolumn{6}{|c|}{ Quasi-isotropic } \\
\hline $\begin{array}{l}\text { Tape } \\
{[45 / 0 /-45 / 90]_{6 s}}\end{array}$ & 누 & $\begin{array}{l}92.0 \\
99.3\end{array}$ & $\begin{array}{l}6.61 \\
6.65\end{array}$ & $\begin{array}{l}.314 \\
.300\end{array}$ & $\begin{array}{l}1.31 \\
1.50\end{array}$ \\
\hline $\begin{array}{l}\text { Fabric } \\
\text { film-stacked } \\
{[45 \mathrm{~F} / 0 \mathrm{~F}]_{68}}\end{array}$ & 노 & $\begin{array}{l}83.0 \\
86.4\end{array}$ & $\begin{array}{l}6.52 \\
6.73\end{array}$ & $\begin{array}{l}.306 \\
.285\end{array}$ & $\begin{array}{l}1.16 \\
1.18\end{array}$ \\
\hline $\begin{array}{l}\text { co-mingled } \\
{[45 \mathrm{~F} / 0 \mathrm{~F}]_{6 s}}\end{array}$ & L & $\begin{array}{l}84.3 \\
81.9\end{array}$ & $\begin{array}{l}6.49 \\
6.48\end{array}$ & $\begin{array}{l}.306 \\
.309\end{array}$ & $\begin{array}{l}1.27 \\
1.23\end{array}$ \\
\hline \multicolumn{6}{|c|}{ Unidirectional } \\
\hline $\operatorname{Tap}_{48}$ & $\frac{\mathrm{L}}{\mathrm{T}}$ & $\begin{array}{c}\text { (b) } \\
24.8\end{array}$ & $\begin{array}{c}17.62 \\
1.49\end{array}$ & $\begin{array}{l}.273 \\
.020\end{array}$ & $\begin{array}{l}\text { (b) } \\
2.2\end{array}$ \\
\hline \multicolumn{6}{|c|}{ Orthotropic } \\
\hline $\begin{array}{l}\text { Tape } \\
{[0 / 90]_{12 \mathrm{~s}}}\end{array}$ & $\frac{L}{T}$ & $\begin{array}{l}72.3 \\
80.1\end{array}$ & $\begin{array}{l}9.08 \\
8.81\end{array}$ & $\begin{array}{l}.040 \\
.040\end{array}$ & $\begin{array}{l}0.08 \\
0.08\end{array}$ \\
\hline $\begin{array}{l}\text { Fabric } \\
\text { film-stacked } \\
{[0 \mathrm{~F}]_{12 \mathrm{~s}}}\end{array}$ & $\frac{L}{T}$ & $\begin{array}{l}71.4 \\
71.1\end{array}$ & $\begin{array}{l}9.00 \\
8.81\end{array}$ & $\begin{array}{l}.005 \\
.005\end{array}$ & $\begin{array}{l}0.81 \\
0.83\end{array}$ \\
\hline $\begin{array}{l}\text { co-mingled } \\
{[\mathrm{OF}]_{128}}\end{array}$ & $\frac{\mathrm{L}}{\mathrm{T}}$ & $\begin{array}{l}84.1 \\
90.3\end{array}$ & $\begin{array}{l}8.77 \\
9.00\end{array}$ & $\begin{array}{l}.006 \\
.005\end{array}$ & $\begin{array}{l}0.95 \\
1.03\end{array}$ \\
\hline
\end{tabular}
(a) L - Longintudinal Direction
T - Transverse Direction
(b) End failures 
Table 5

Average shear moduli of graphite/PEEK laminates

\begin{tabular}{|c|c|c|c|}
\hline $\begin{array}{c}\text { Laminate } \\
\text { Type }\end{array}$ & $\begin{array}{c}\text { Direction } \\
(a)\end{array}$ & $\begin{array}{c}\text { Young's } \\
\text { Modulus, } \\
\text { msi }\end{array}$ & $\begin{array}{c}\text { Secant } \\
\text { Modulus } \\
\text { msi }\end{array}$ \\
\hline \multicolumn{4}{|c|}{ Quasi-isotropic } \\
\hline $\begin{array}{l}\text { Tape } \\
{[45 / 0 /-45 / 90]_{6 s}}\end{array}$ & $\frac{L}{T}$ & $\begin{array}{l}3.51 \\
3.78\end{array}$ & $\begin{array}{l}2.46 \\
2.26\end{array}$ \\
\hline $\begin{array}{l}\text { Fabric } \\
\text { film-stacked } \\
{[45 \mathrm{~F} / \mathrm{OF}]_{6 \mathrm{~s}}}\end{array}$ & L & $\begin{array}{l}2.11 \\
2.14\end{array}$ & \\
\hline $\begin{array}{l}\text { co-mingled } \\
{[45 \mathrm{~F} / 0 \mathrm{~F}]_{6 s}}\end{array}$ & L & $\begin{array}{l}2.25 \\
2.18\end{array}$ & \\
\hline \multicolumn{4}{|c|}{ Unidirectional } \\
\hline $\begin{array}{l}\text { Tape } \\
{[0]_{48}}\end{array}$ & $\stackrel{\mathrm{L}}{\mathrm{T}}$ & $\begin{array}{l}0.99 \\
0.53\end{array}$ & \\
\hline \multicolumn{4}{|c|}{ Orthotropic } \\
\hline $\begin{array}{l}\text { Tape } \\
{[0 / 90]_{12 s}}\end{array}$ & 누 & $\begin{array}{l}0.93 \\
0.72\end{array}$ & $\begin{array}{l}0.70 \\
0.58\end{array}$ \\
\hline $\begin{array}{l}\text { Fabric } \\
\text { film-stacked } \\
{[\mathrm{OF}]_{12 \mathrm{~s}}}\end{array}$ & $\frac{\mathrm{L}}{\mathrm{T}}$ & $\begin{array}{l}0.65 \\
0.54\end{array}$ & $\begin{array}{l}0.58 \\
0.55\end{array}$ \\
\hline $\begin{array}{l}\text { co-mingled } \\
{[\mathrm{OF}]_{12 \mathrm{~s}}}\end{array}$ & L & $\begin{array}{l}0.65 \\
0.49\end{array}$ & $\begin{array}{l}0.60 \\
0.55\end{array}$ \\
\hline
\end{tabular}

(a) L- Longintudinal Direction

$T$ - Transverse Direction 
Table 6

Notched compresion test results

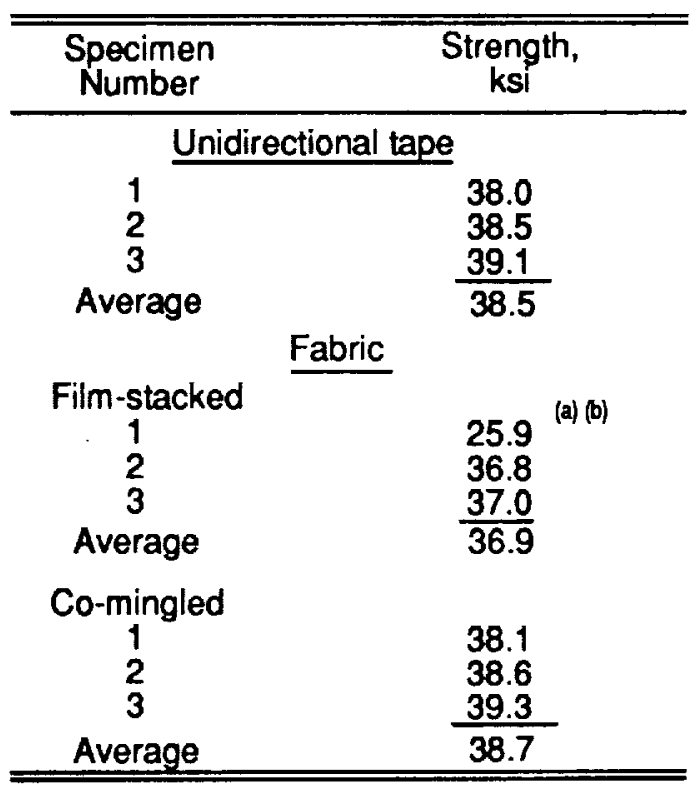

(a) Did not fail through hole

(b) Not used in average

Table 7

Compression-after-impact test results

\begin{tabular}{|c|c|c|c|}
\hline $\begin{array}{l}\text { Specimen } \\
\text { Number }\end{array}$ & $\begin{array}{c}\text { Impact } \\
\text { Energy, } \\
\mathrm{tt}-\mathrm{lb}\end{array}$ & $\begin{array}{c}\text { Damage } \\
\text { Area, } \\
\text { sq. in. } \\
\end{array}$ & $\begin{array}{c}\text { Residual } \\
\text { Strength, } \\
\text { ksi }\end{array}$ \\
\hline \multicolumn{4}{|c|}{ Unidirectional tape } \\
\hline $\begin{array}{l}1 \\
2 \\
3\end{array}$ & $\begin{array}{l}20.8 \\
20.8 \\
20.8\end{array}$ & $\begin{array}{l}2.98 \\
2.56 \\
2.76\end{array}$ & $\begin{array}{l}32.0 \\
30.1 \\
30.0\end{array}$ \\
\hline Average & & 2.77 & 30.7 \\
\hline \multicolumn{4}{|c|}{ Fabric } \\
\hline $\begin{array}{c}\text { Film-stacked } \\
1 \\
2 \\
3 \\
\text { Average }\end{array}$ & $\begin{array}{l}10.9 \\
19.7 \\
19.7\end{array}$ & $\begin{array}{l}2.03^{\text {(a) }} \\
2.67 \\
2.36 \\
2.52\end{array}$ & $\begin{array}{l}32.8^{(a)} \\
38.1 \\
\frac{38.3}{38.2}\end{array}$ \\
\hline $\begin{array}{c}\text { Co-mingled } \\
1 \\
2 \\
3\end{array}$ & $\begin{array}{l}19.3 \\
19.1 \\
19.0\end{array}$ & $\begin{array}{l}3.60 \\
3.12 \\
2.70 \\
\end{array}$ & $\begin{array}{l}31.0 \\
29.9 \\
36.1\end{array}$ \\
\hline Average & & $\overline{3.14}$ & 32.3 \\
\hline
\end{tabular}

(a) Not used in average 


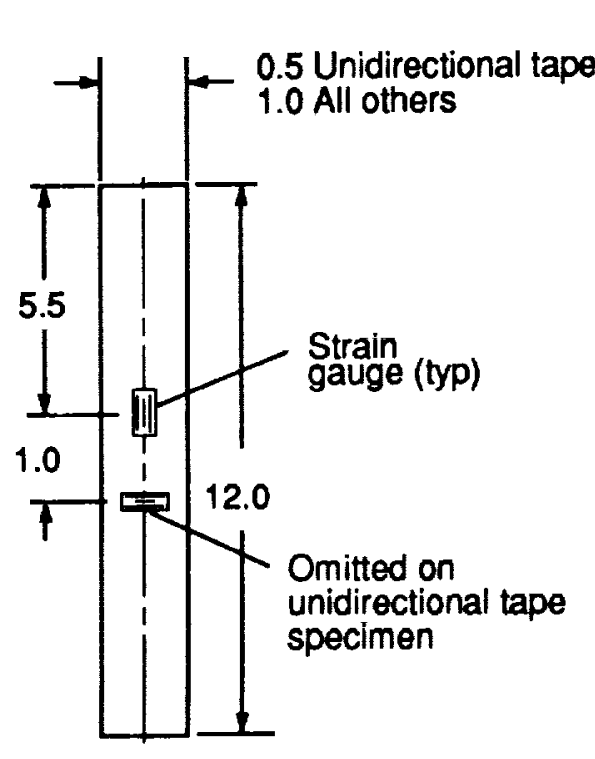

Tension

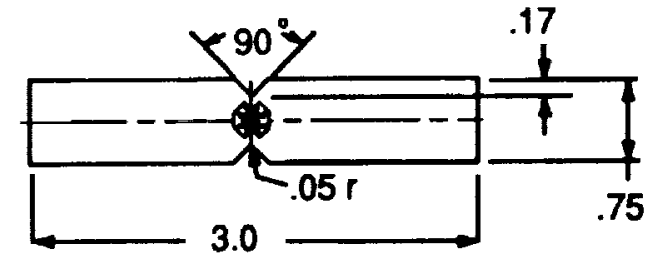

losipescu shear

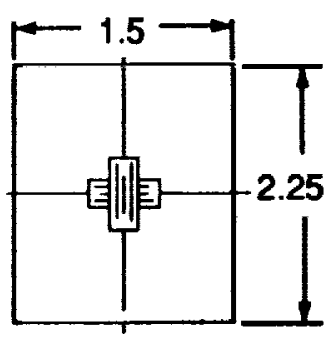

Compression

All strain gauges are back-to-back except on losipescu shear specimen

Figure 1. - Configuration and gage location for tension, compression and shear specimens. All dimensions are in inches.

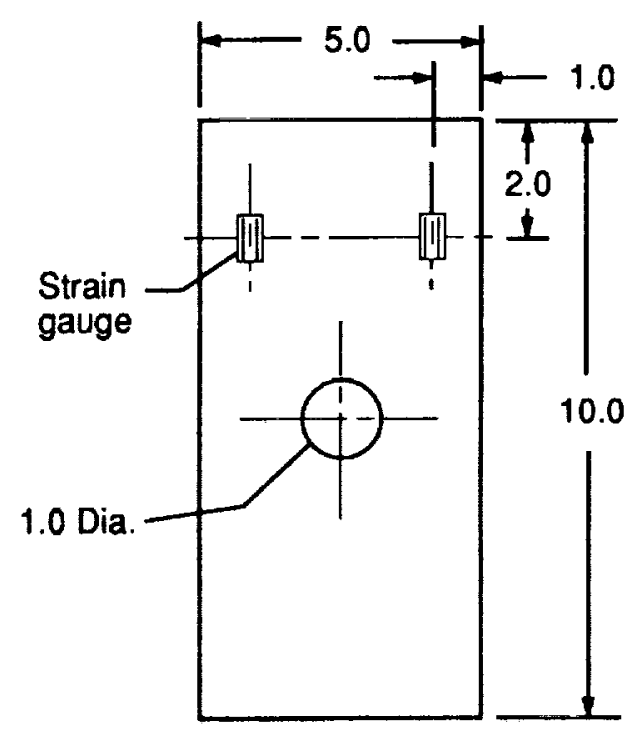

Notched Compression

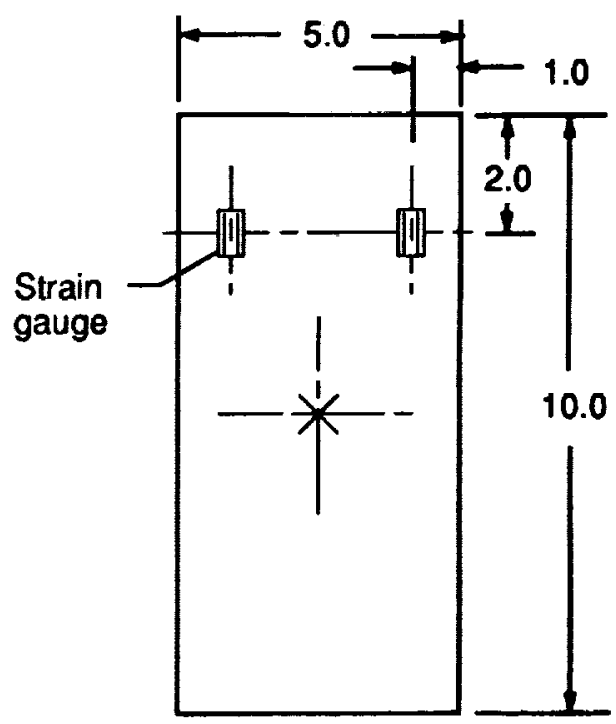

Compression-after-impact

All strain gauges are back-to-back

Figure 2. - Configuration and gage location for compression panels.

All dimensions are in inches. 


\section{ORIGINAL PAGE \\ BLACK AND WHITE PHOTOGRAPH}

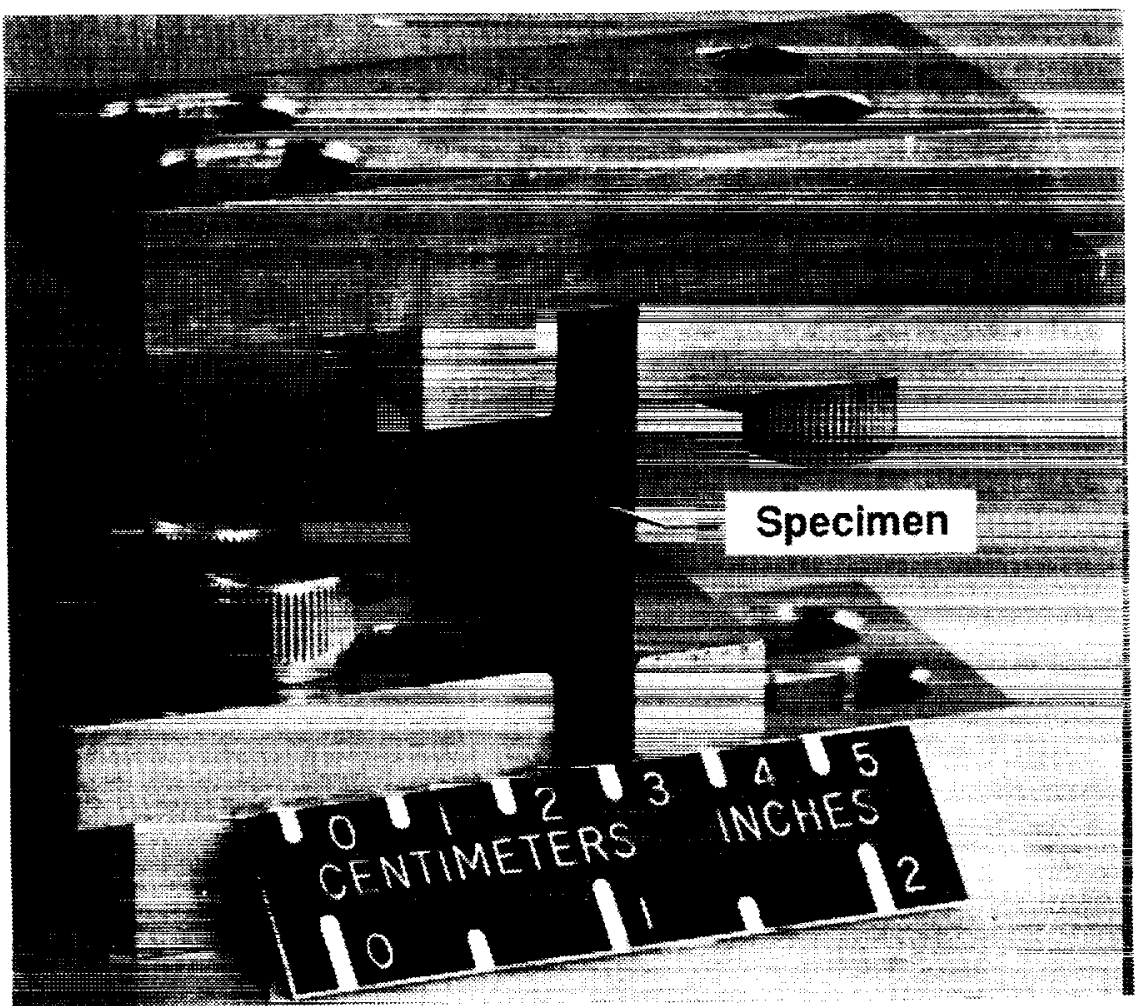

Figure 3.-Fixture for compression tests with specimen installed.

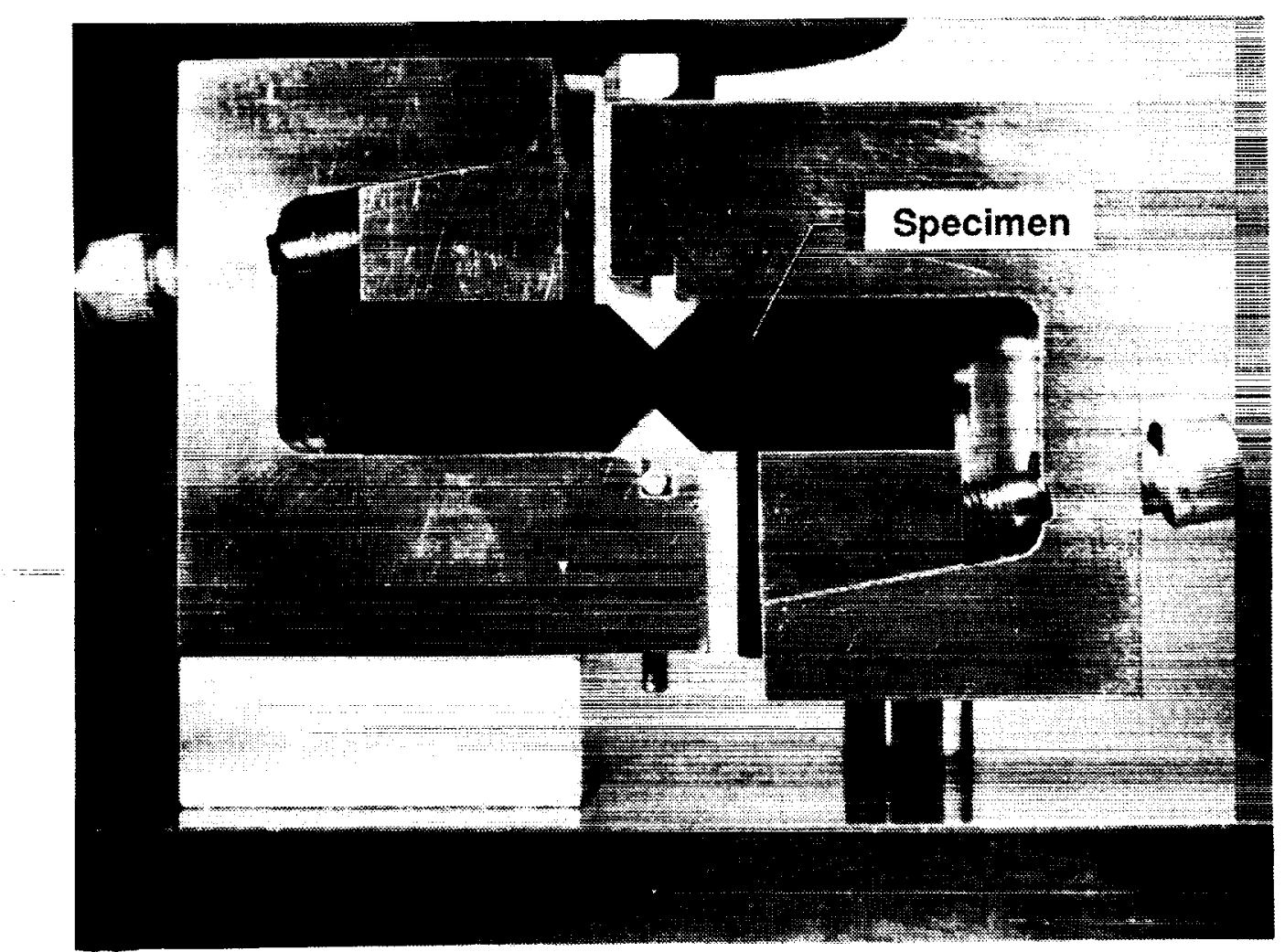

Figure 4.-Fixture for Iosipescu shear test with specimen installed. 


\section{ORIGINAL PAGE \\ BLACK AND WHITE PHOTOGRAPH}

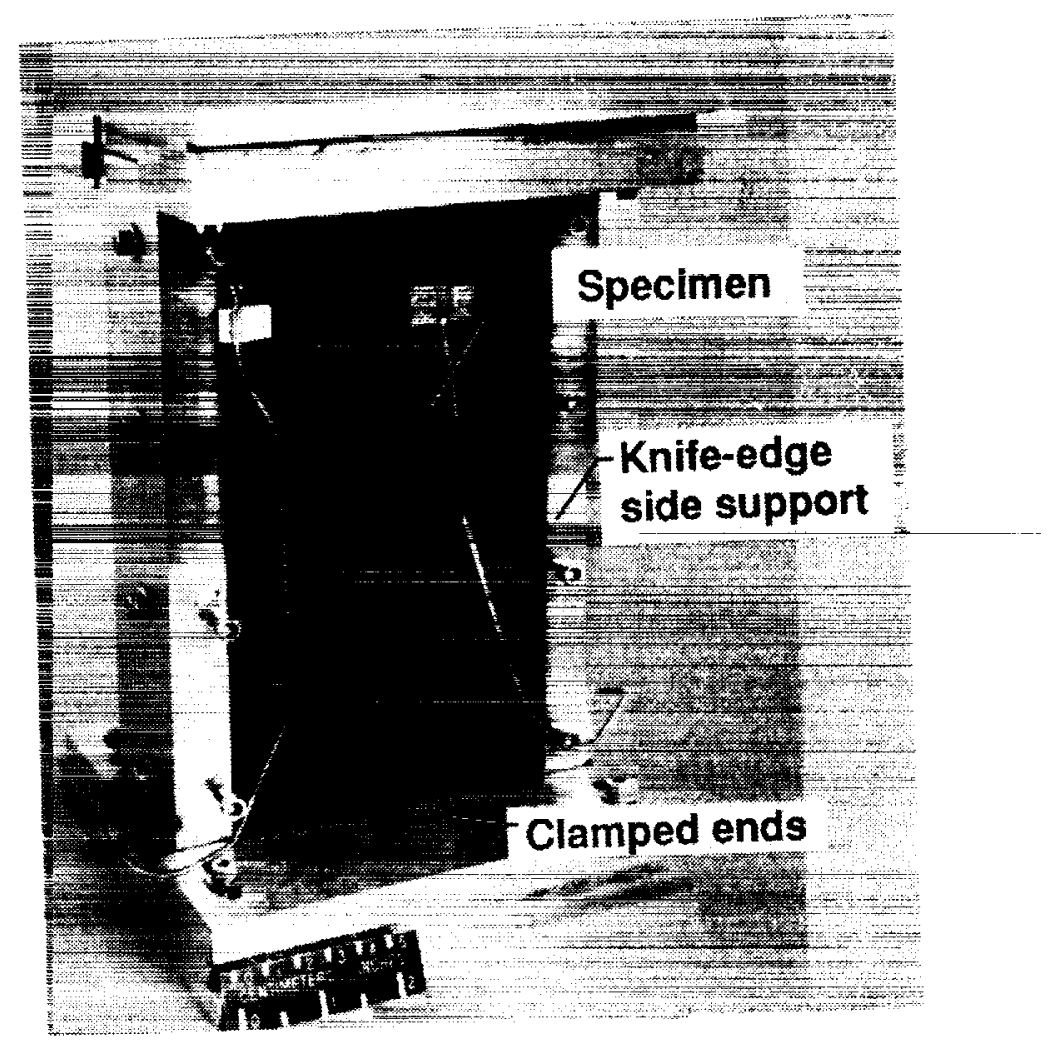

Figure 5.- Fixture for notched compression and compression-after-impact with specimen installed.

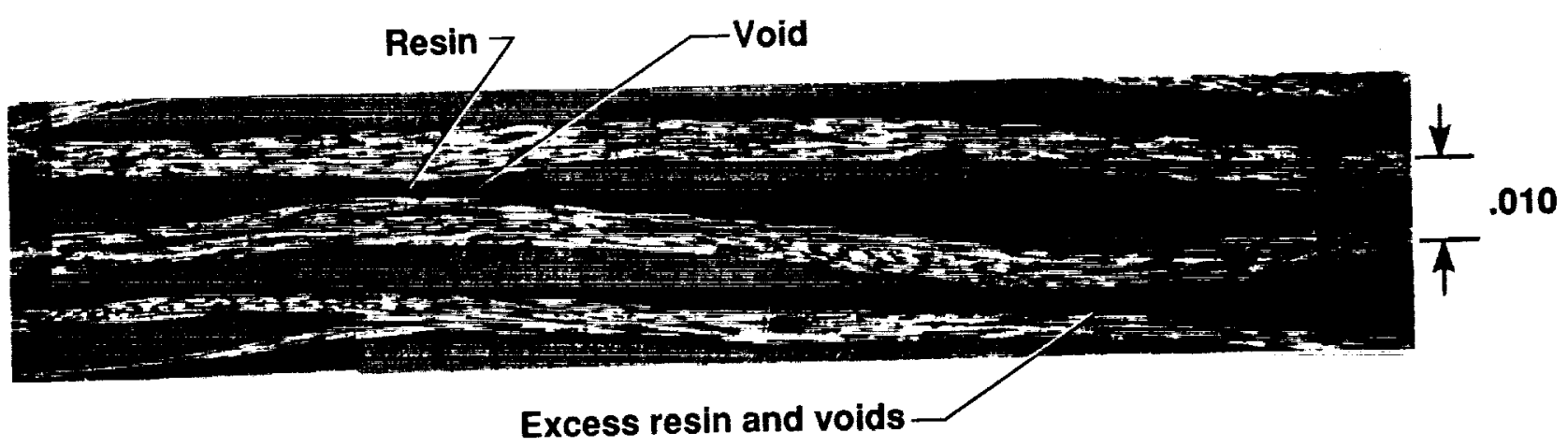

Figure 6.-Photomicrograph of $[0 \mathrm{~F}]_{24}$ co-mingled fabric material.

Dimension is in inches. 


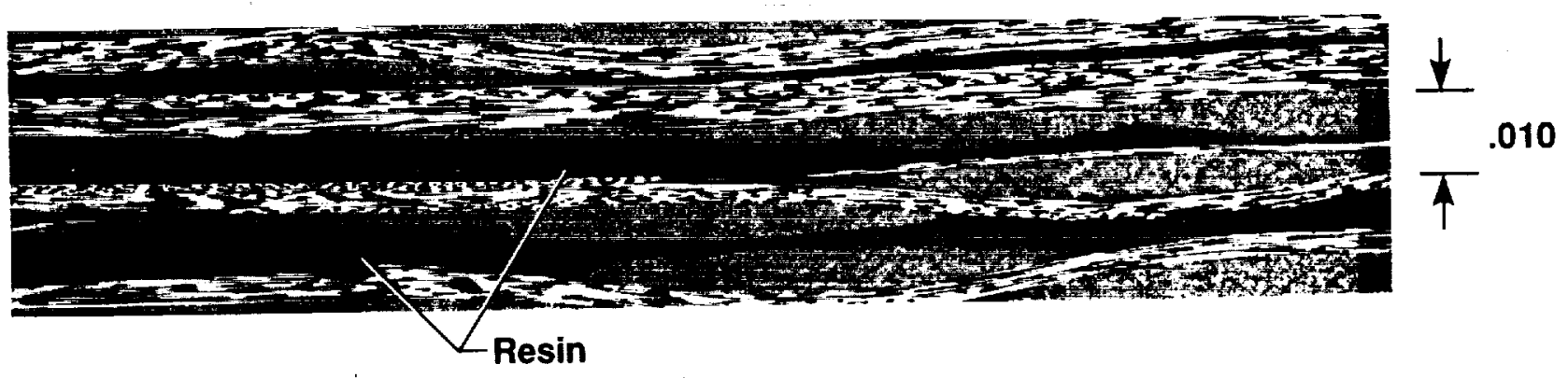

Figure 7. - Photomicrograph of $[0 \mathrm{~F}]_{24}$ film-stacked material. Dimension is in inches.

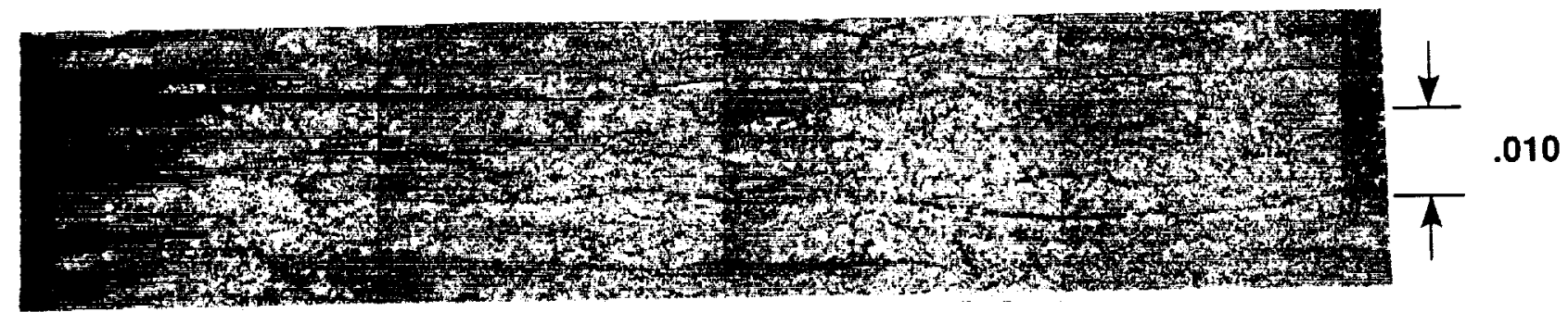

Figure 8. - Photomicrograph of $[0]_{48}$ unidirectional material. Dimension is in inches. 


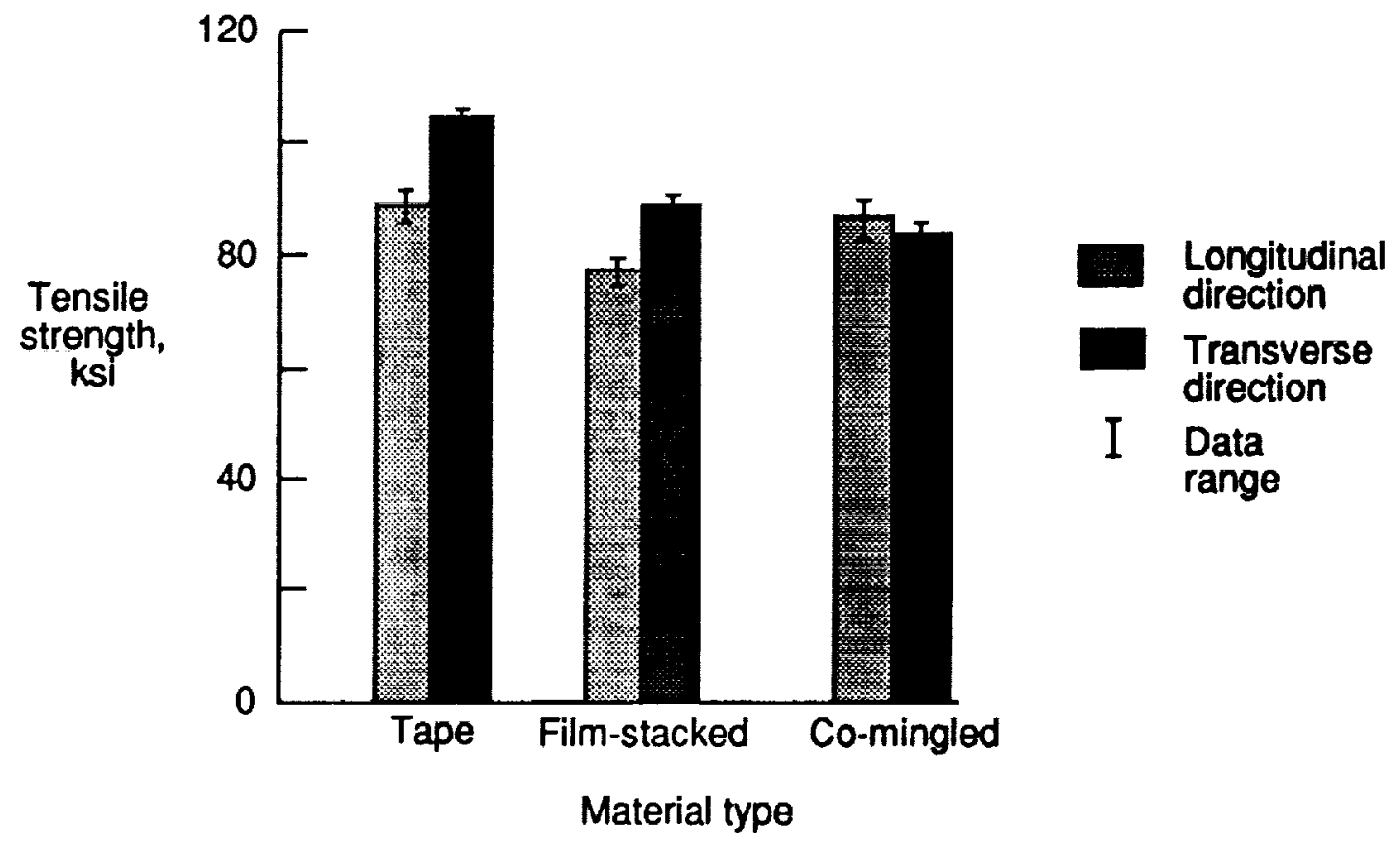

Figure 9.- Tensile strength of quasi-isotropic graphite/PEEK material.

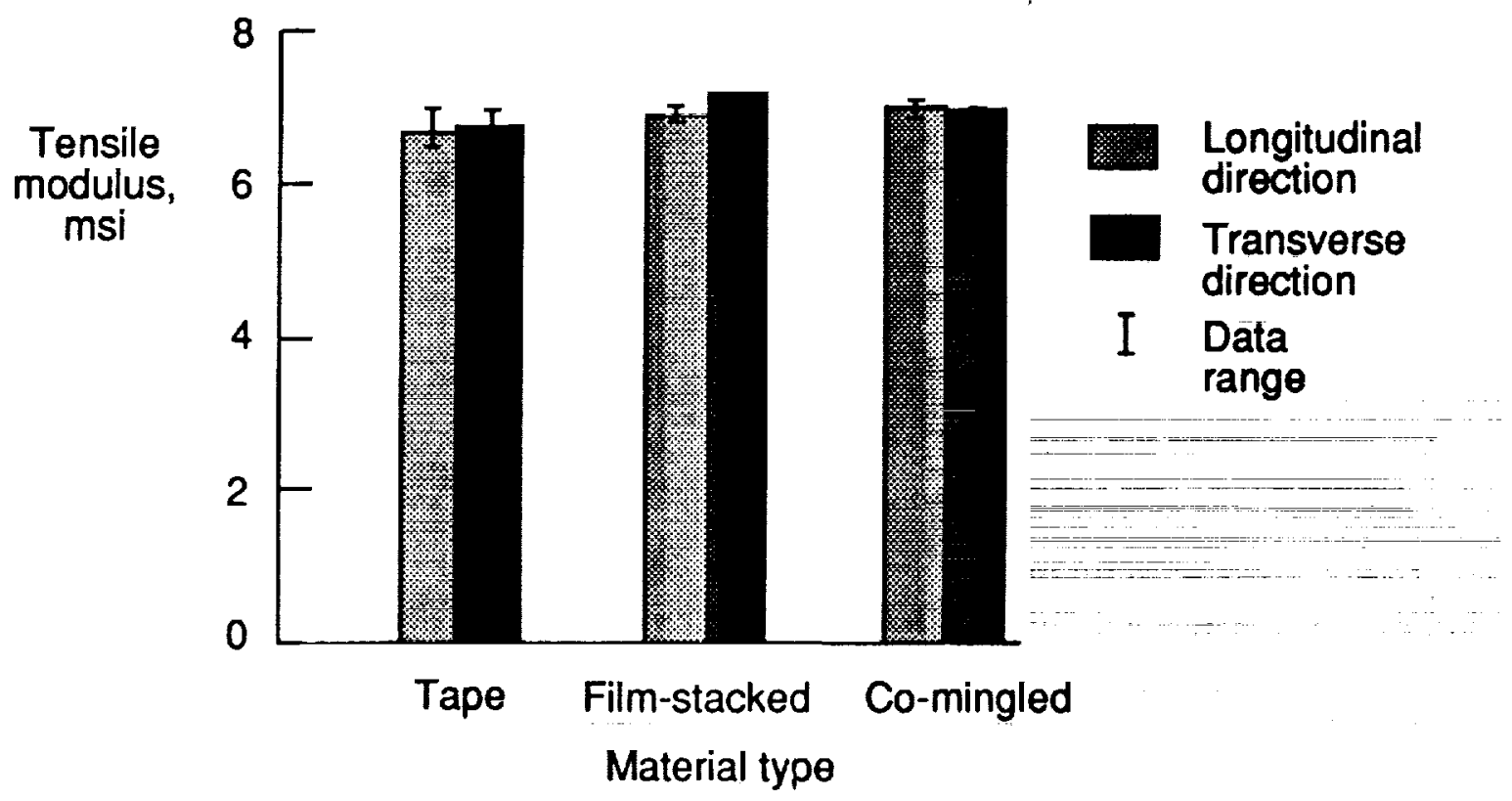

Figure 10. - Tensile moduli of quasi-isotropic graphite/PEEK material. 


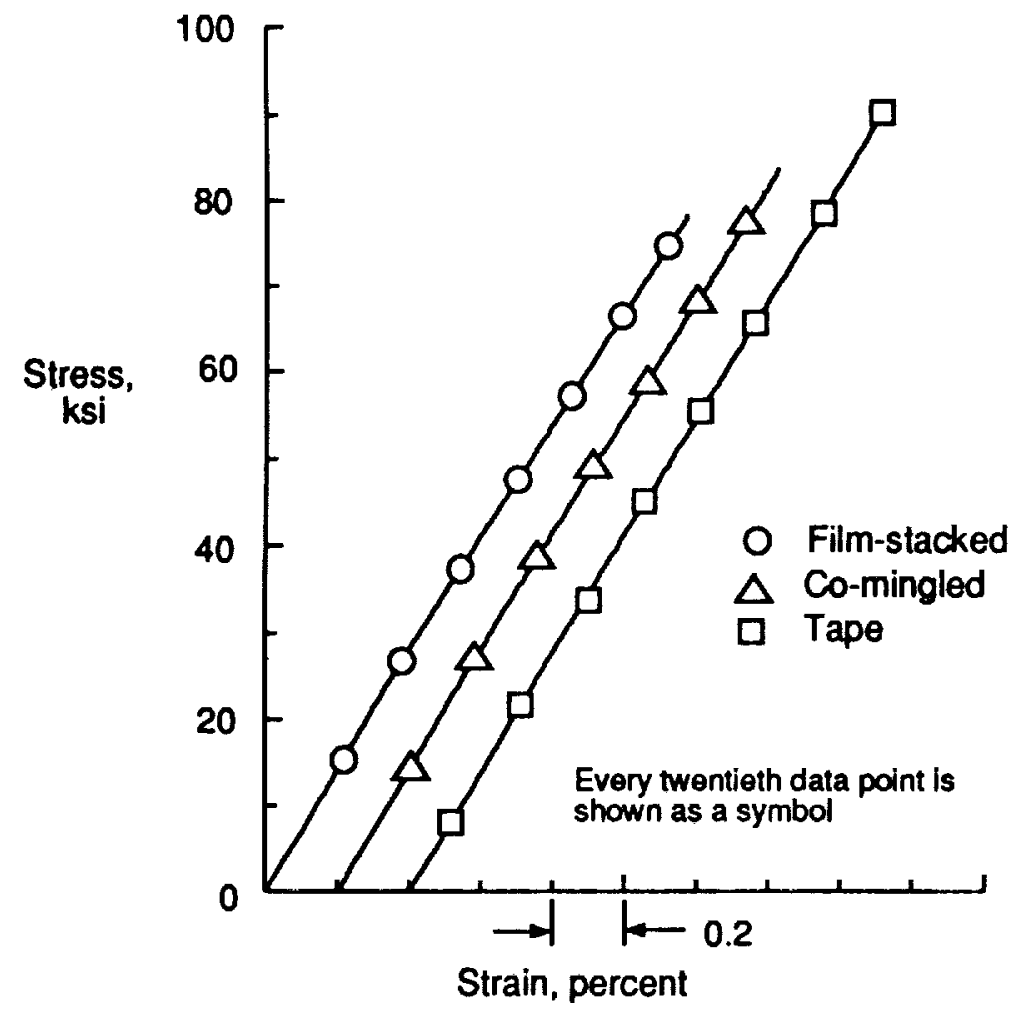

Figure 11. - Stress as a function of strain in longitudinal direction for graphite/PEEK material.

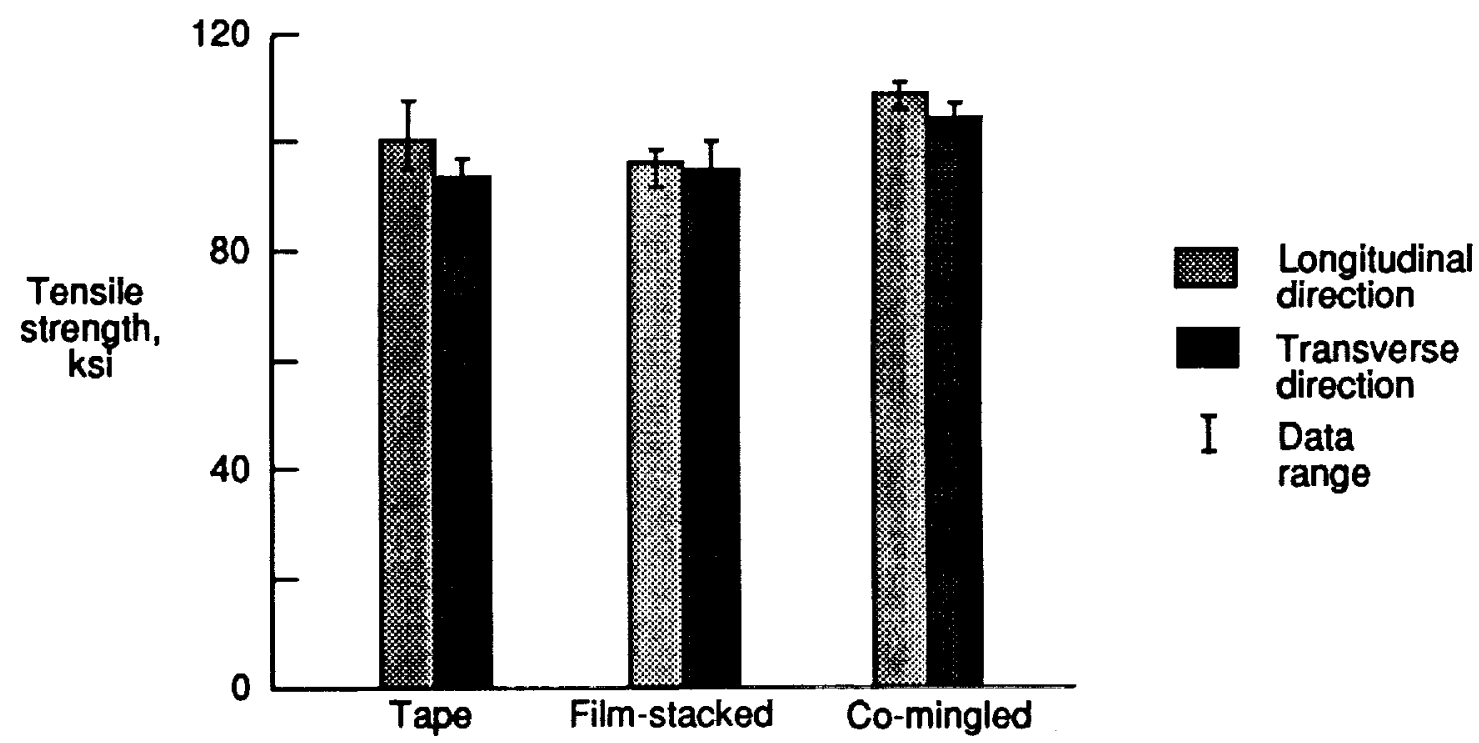

Material type

Figure 12. - Tensile strength of orthotropic graphite/PEEK material. 


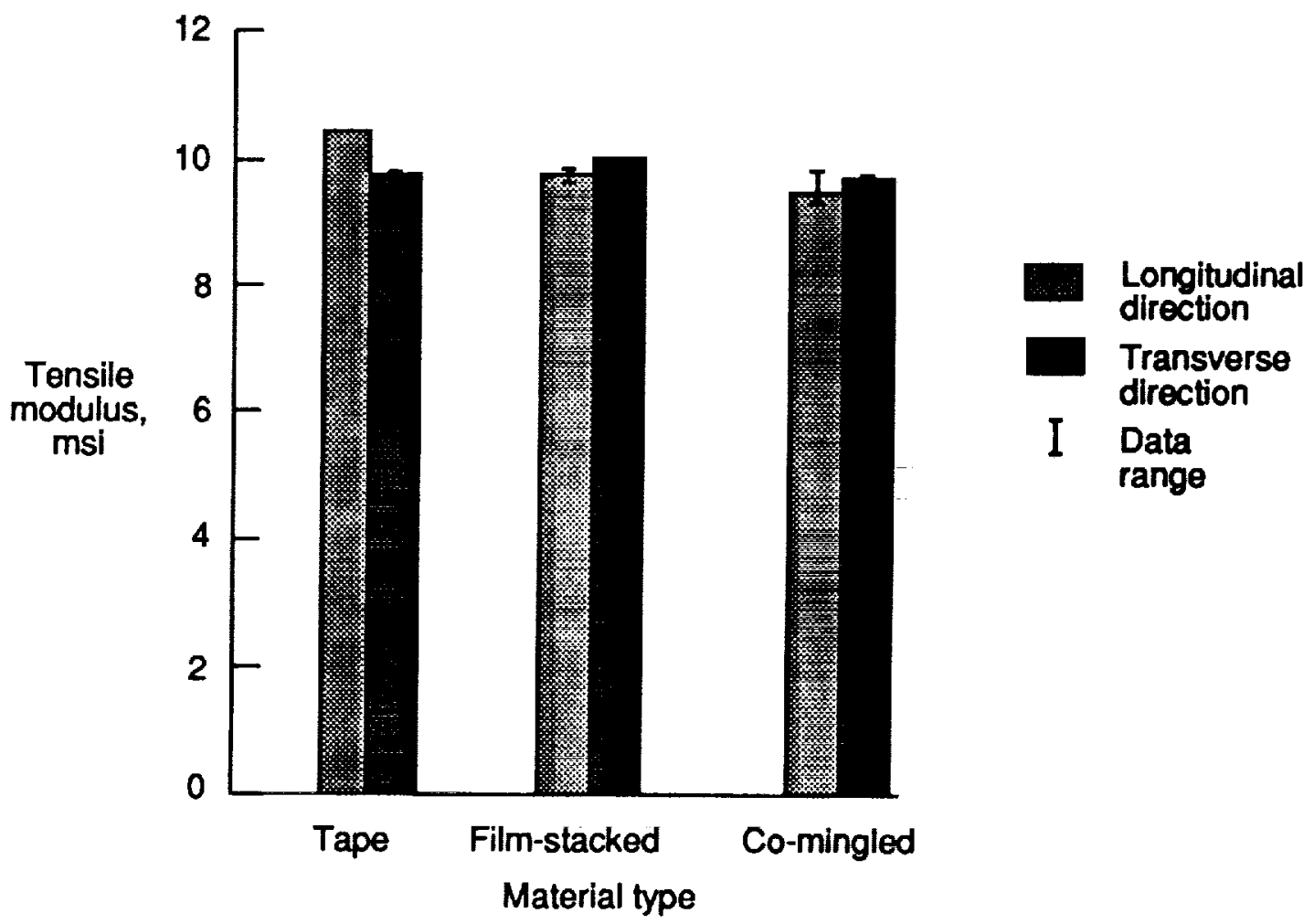

Figure 13 - Tensile modulus of orthotropic graphite/PEEK material.

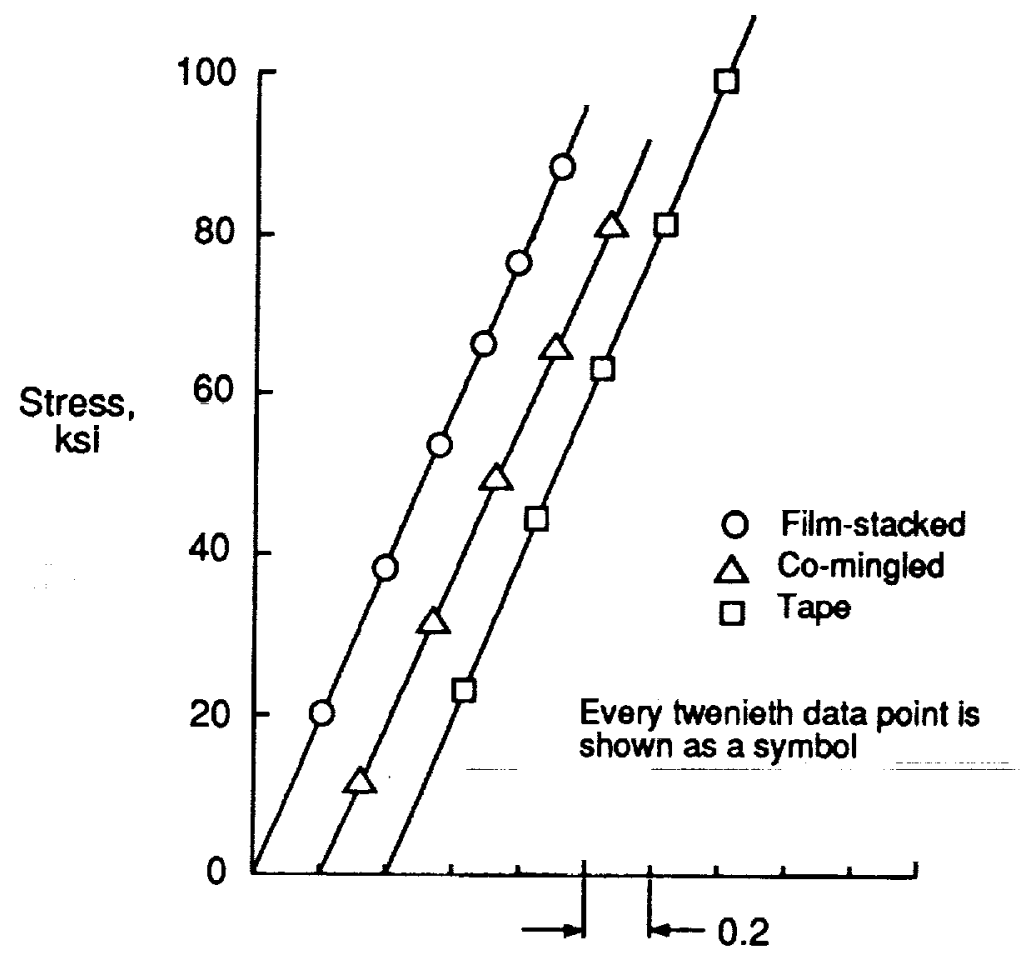

Strain, percent

Figure 14. - Tensile stress-strain curves for orthotropic graphite/PEEK material. 


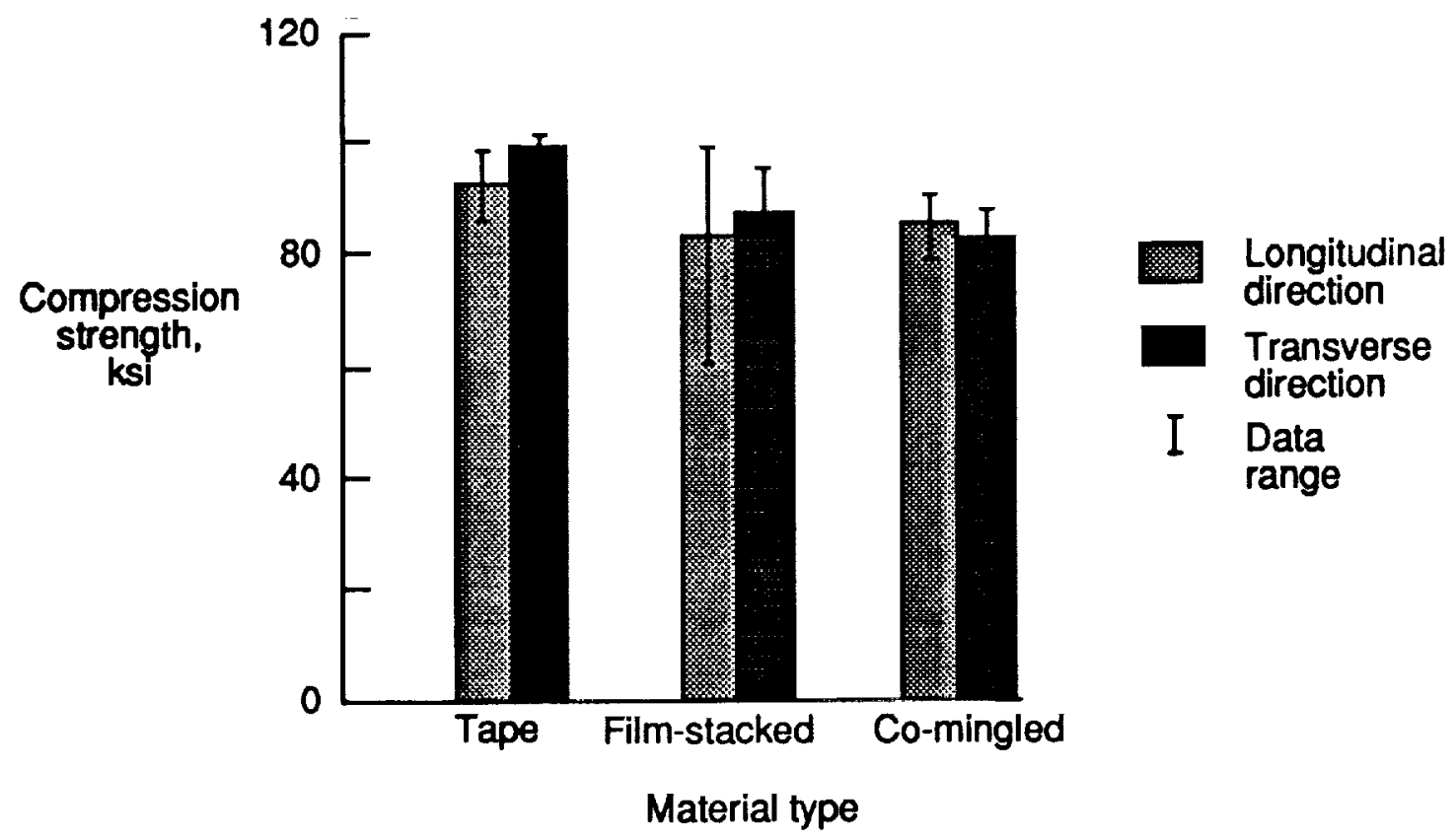

Figure 15. - Compression strength of quasi-isotropic graphite/PEEK material.

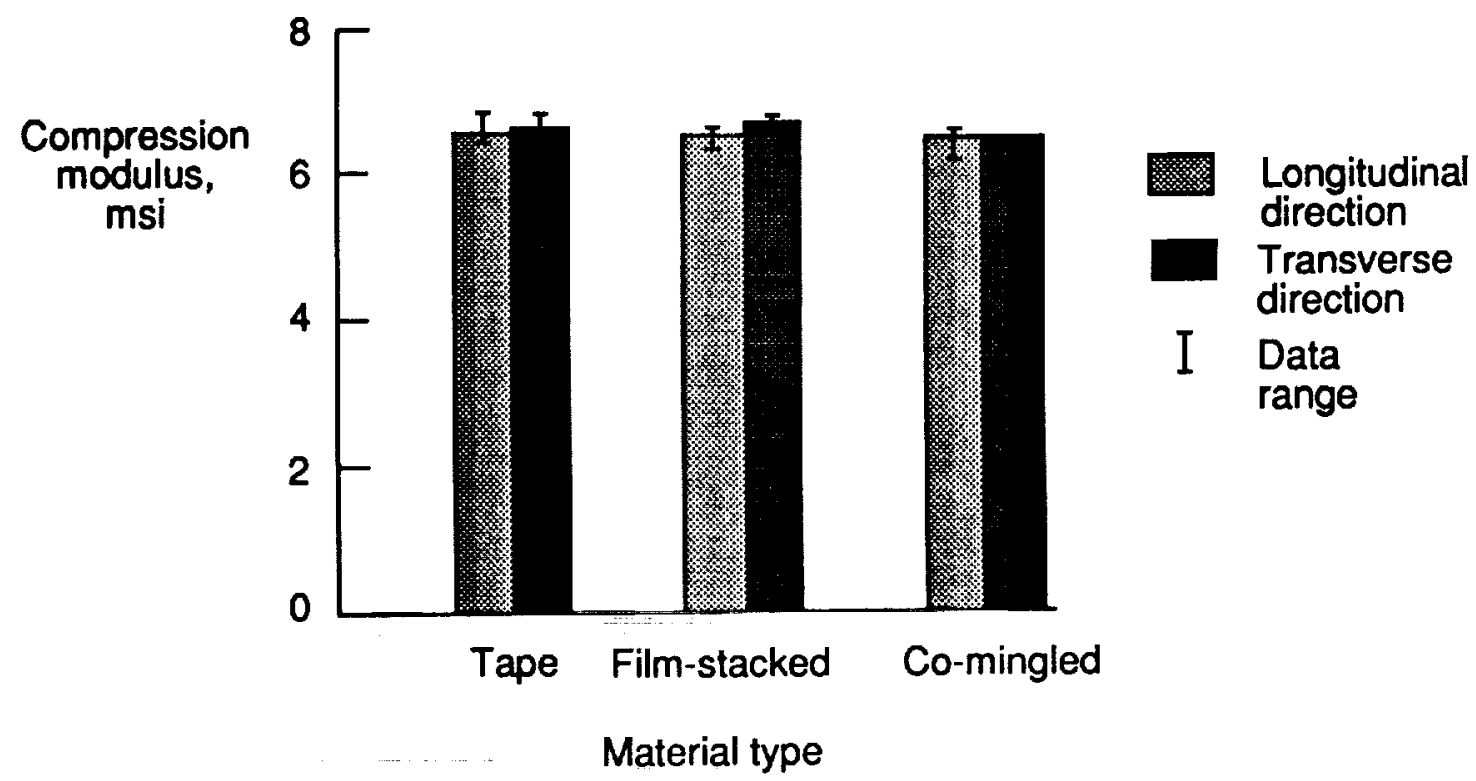

Figure 16. - Compression modulus of quasi-isotropic graphite/PEEK material. 


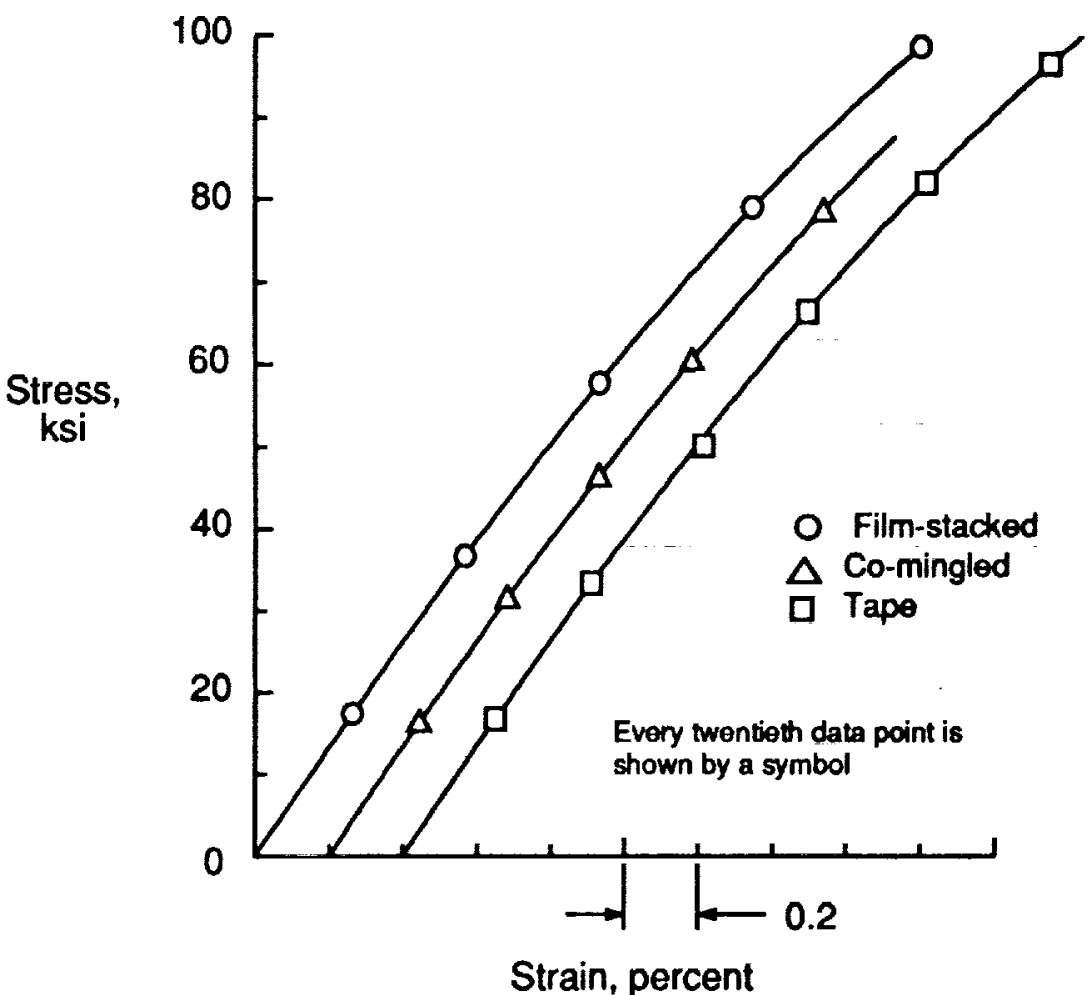

Figure 17. - Compression stress-strain results for quasi-isotropic graphite/PEEK material.

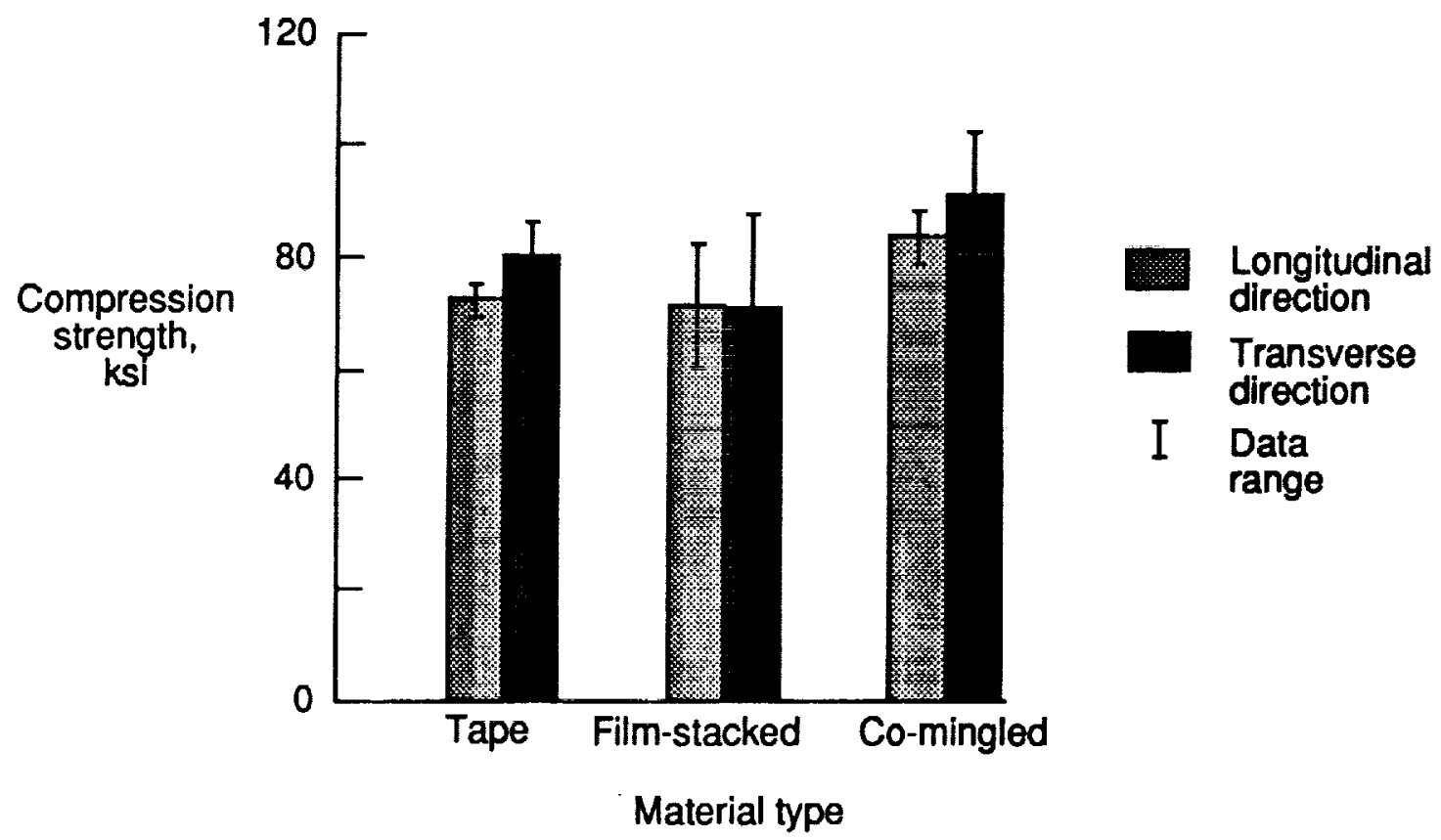

Figure 18. - Compression strength of orthotropic graphite/PEEK material. 


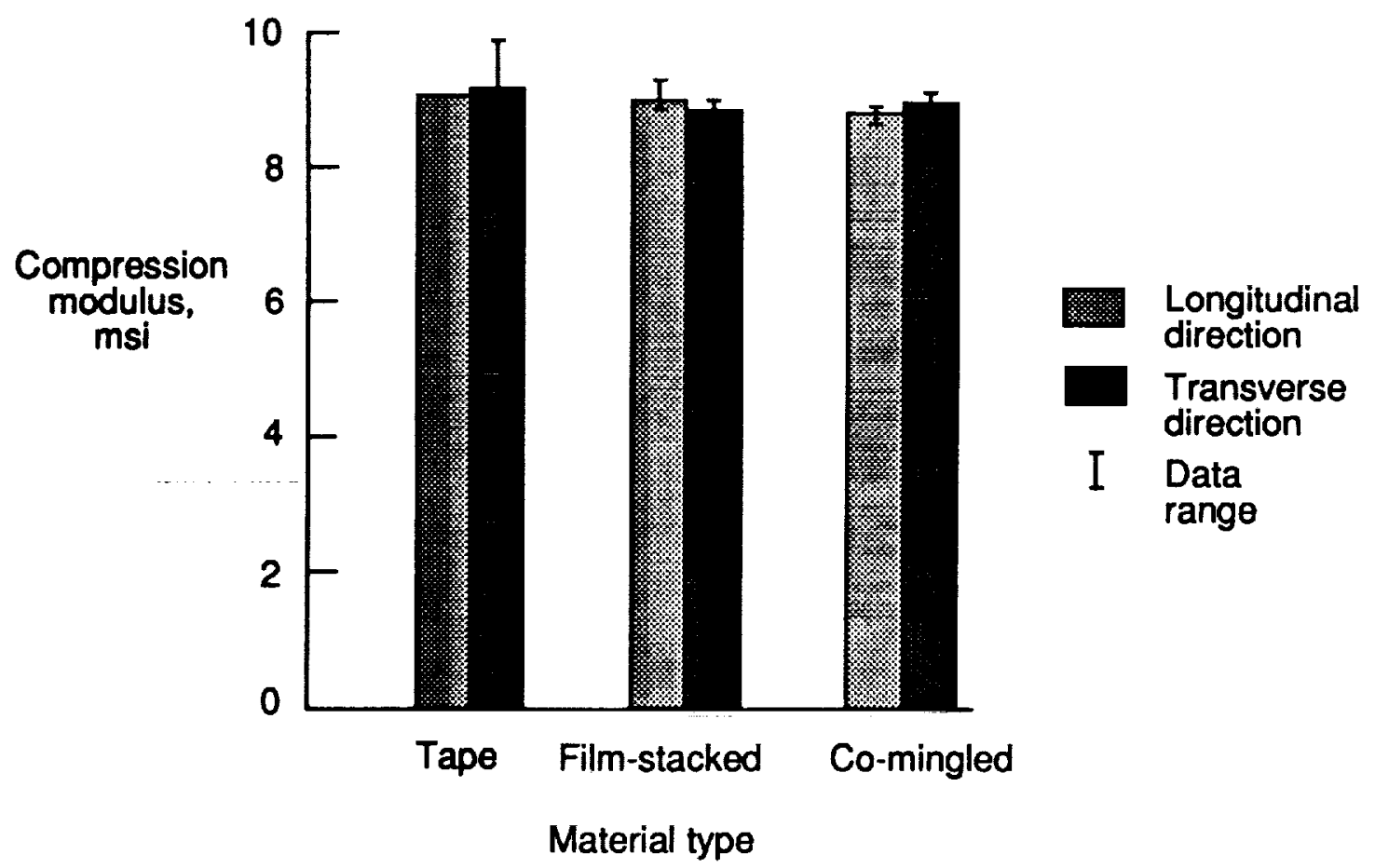

Figure 19. - Compression modulus of orthotropic graphite/PEEK material.

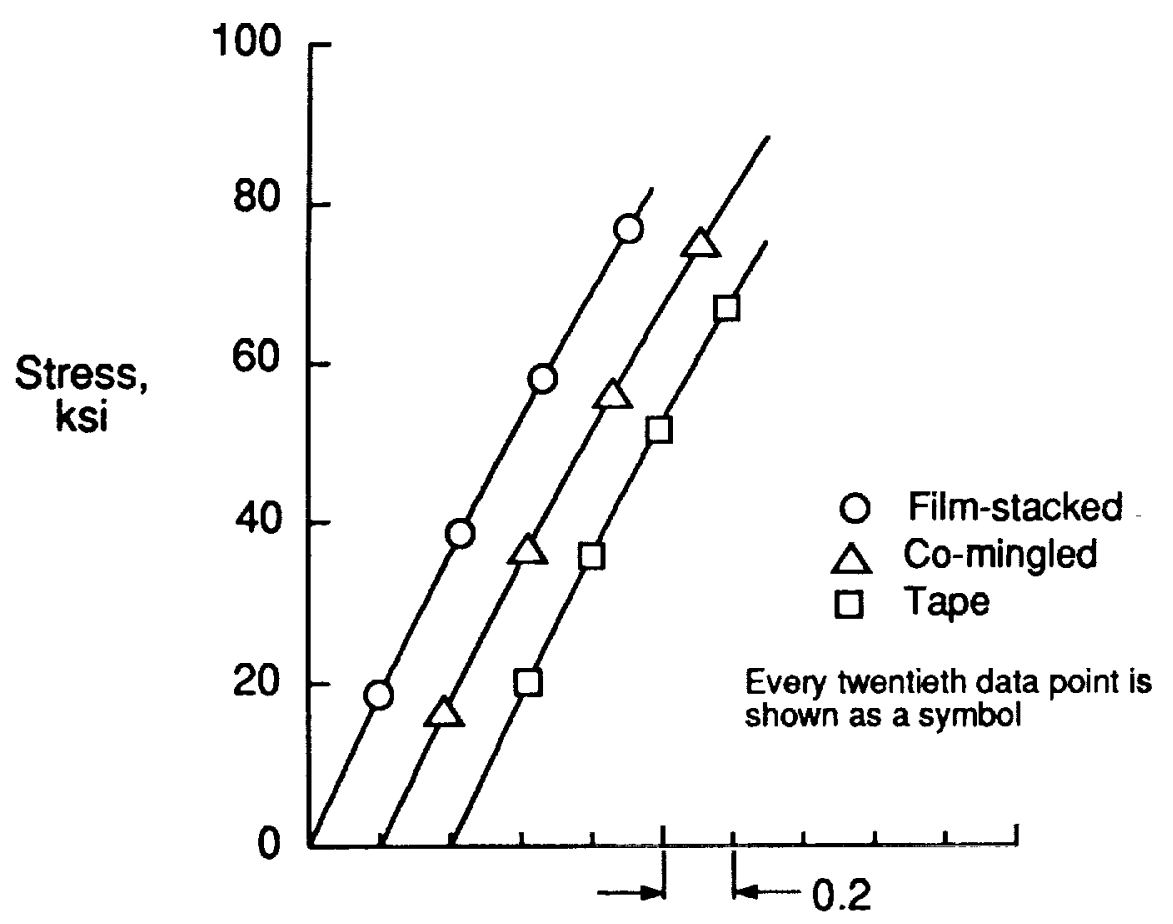

Strain, percent

Figure 20. - Compression stress as a function of strain for orthotropic graphite/PEEK material. 


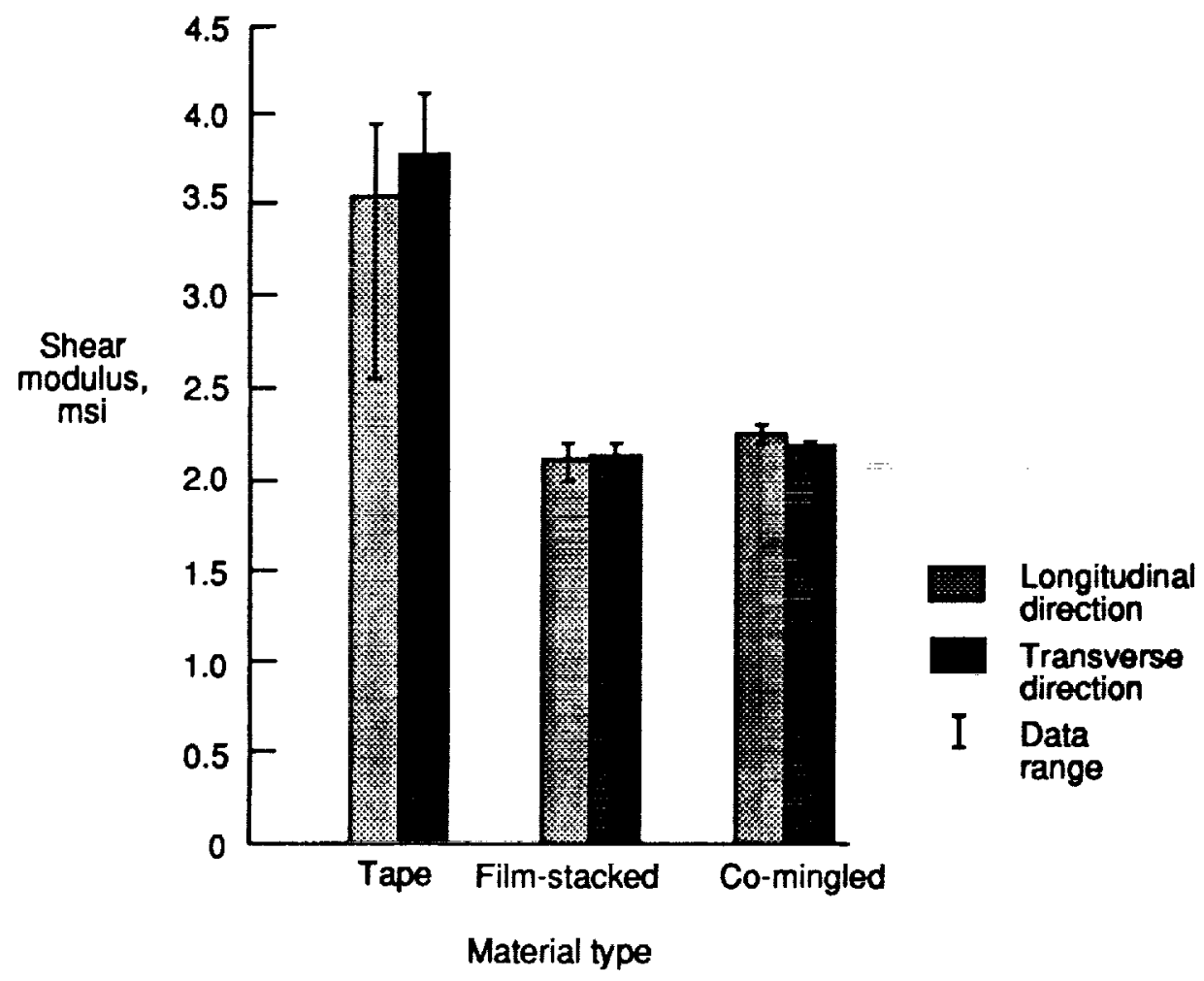

Figure 21. - Shear modulus of quasi-isotropic graphite/PEEK material.

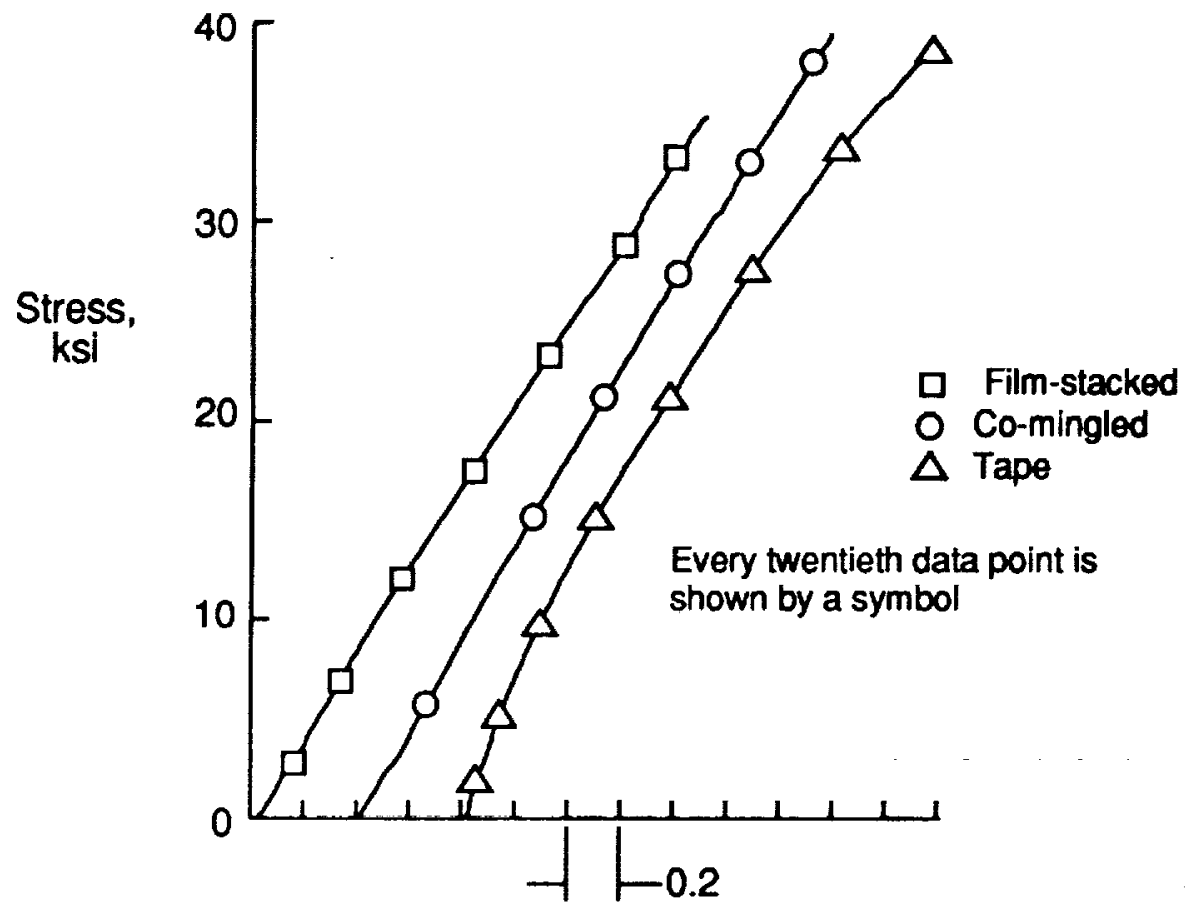

Strain, percent

Figure 22. - Shear stress-strain results for quasi-isotropic graphite/PEEK material. 


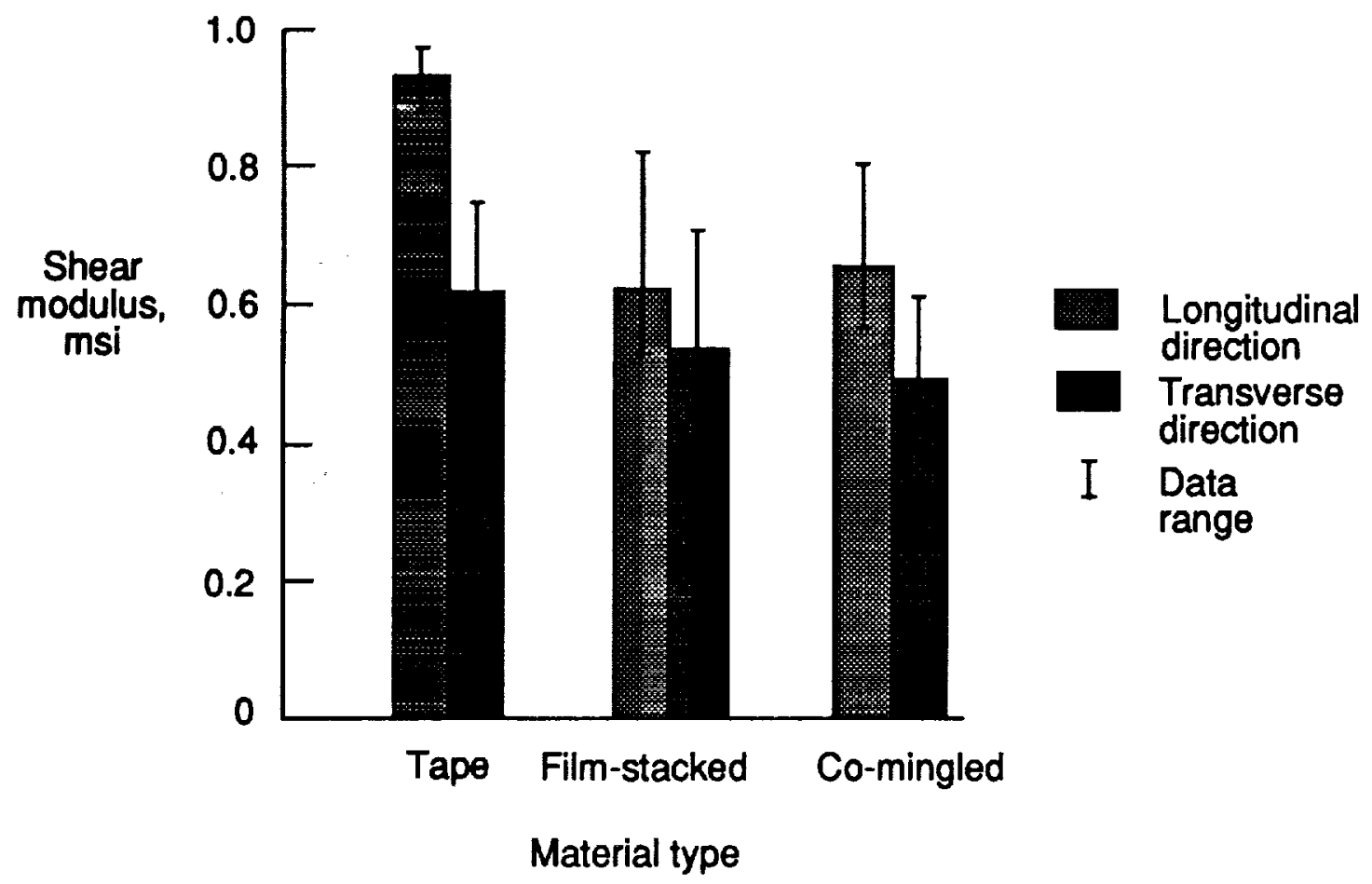

Figure 23. - Shear modulus of orthotropic graphite/PEEK material.

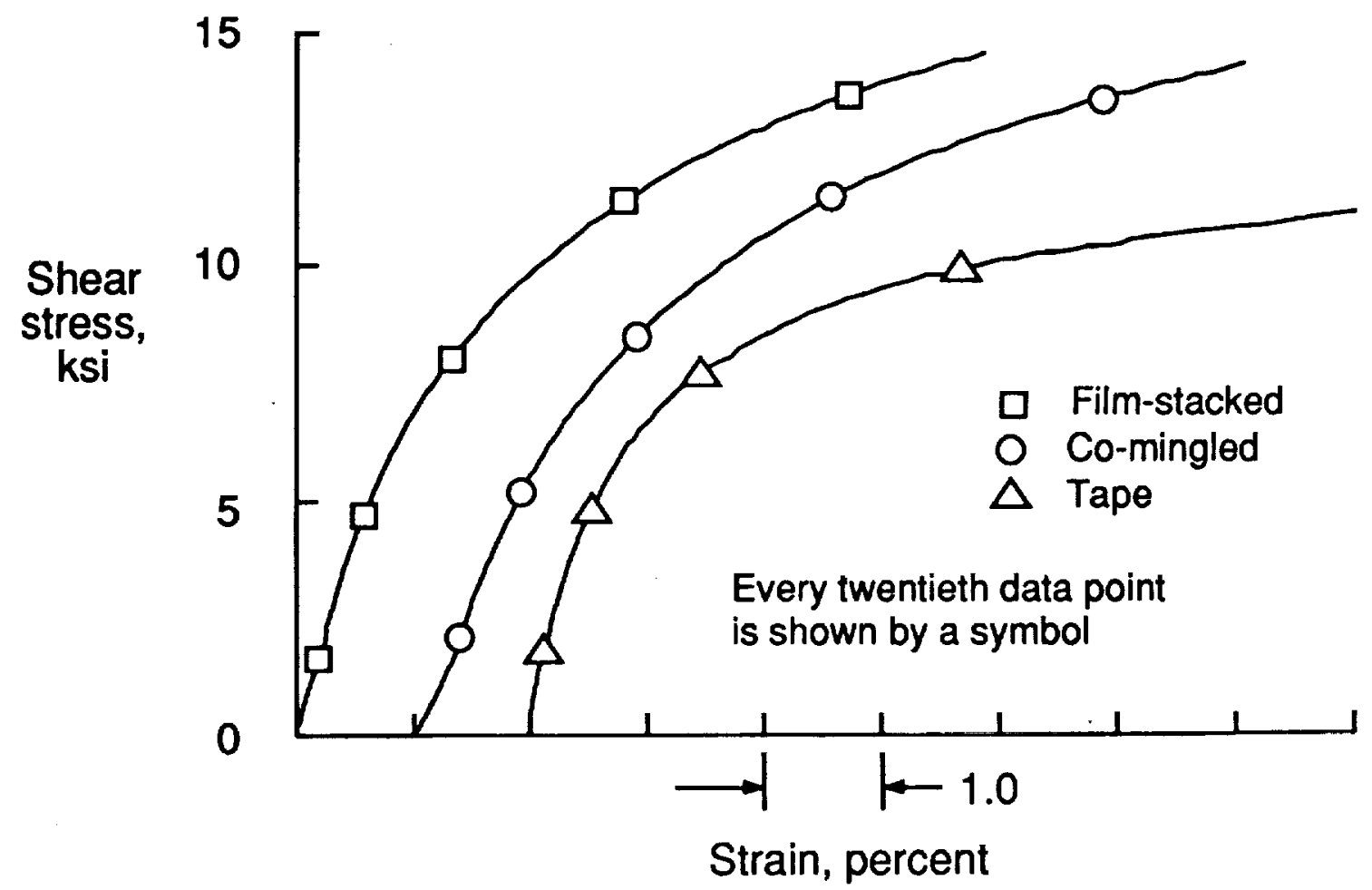

Figure 24. - Shear stress-strain results for orthotropic graphite/PEEK material. 

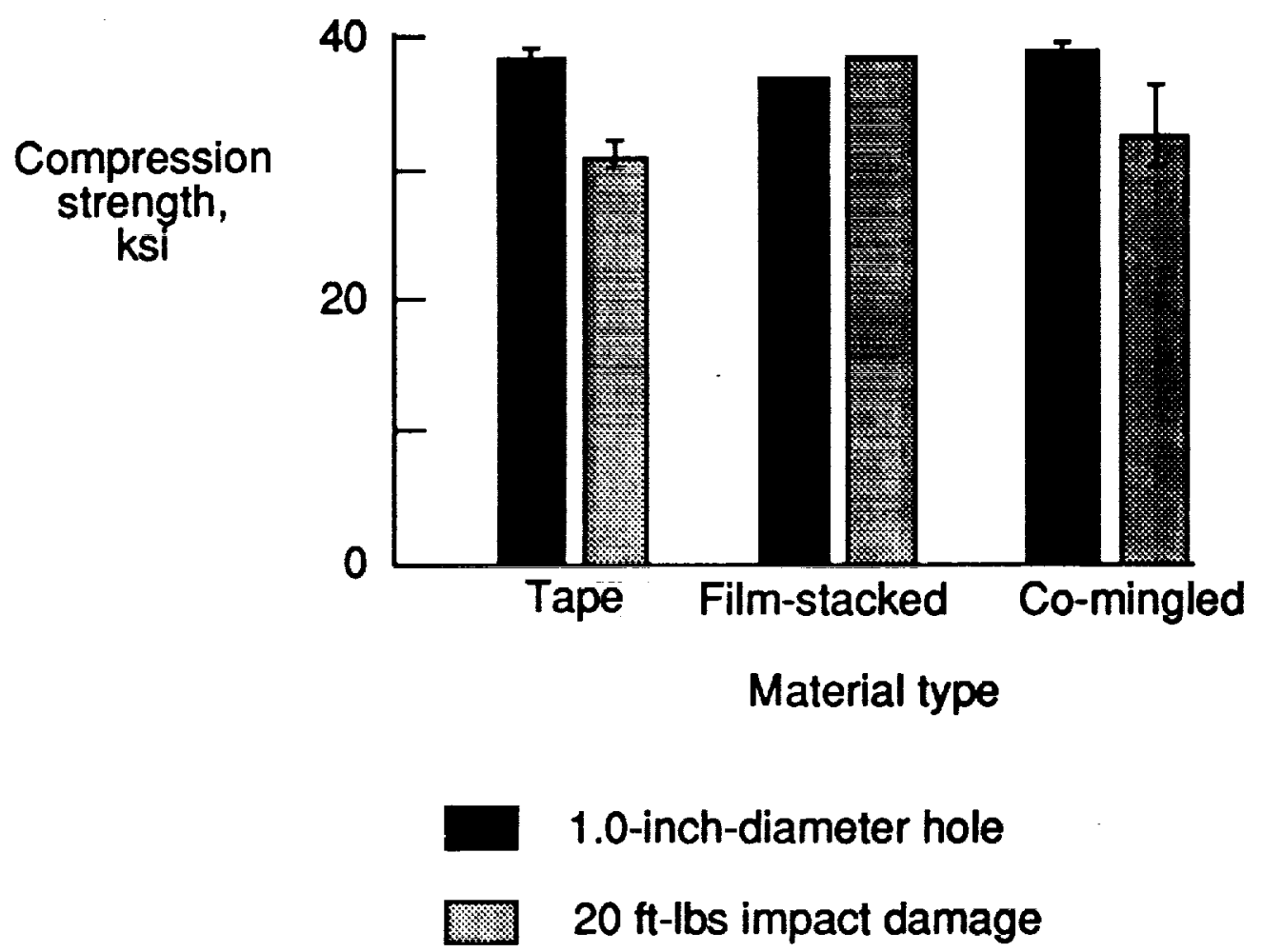

Figure 25. - Compression strength of notched and impact damaged quasi-isotropic graphite/PEEK material. 


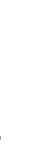




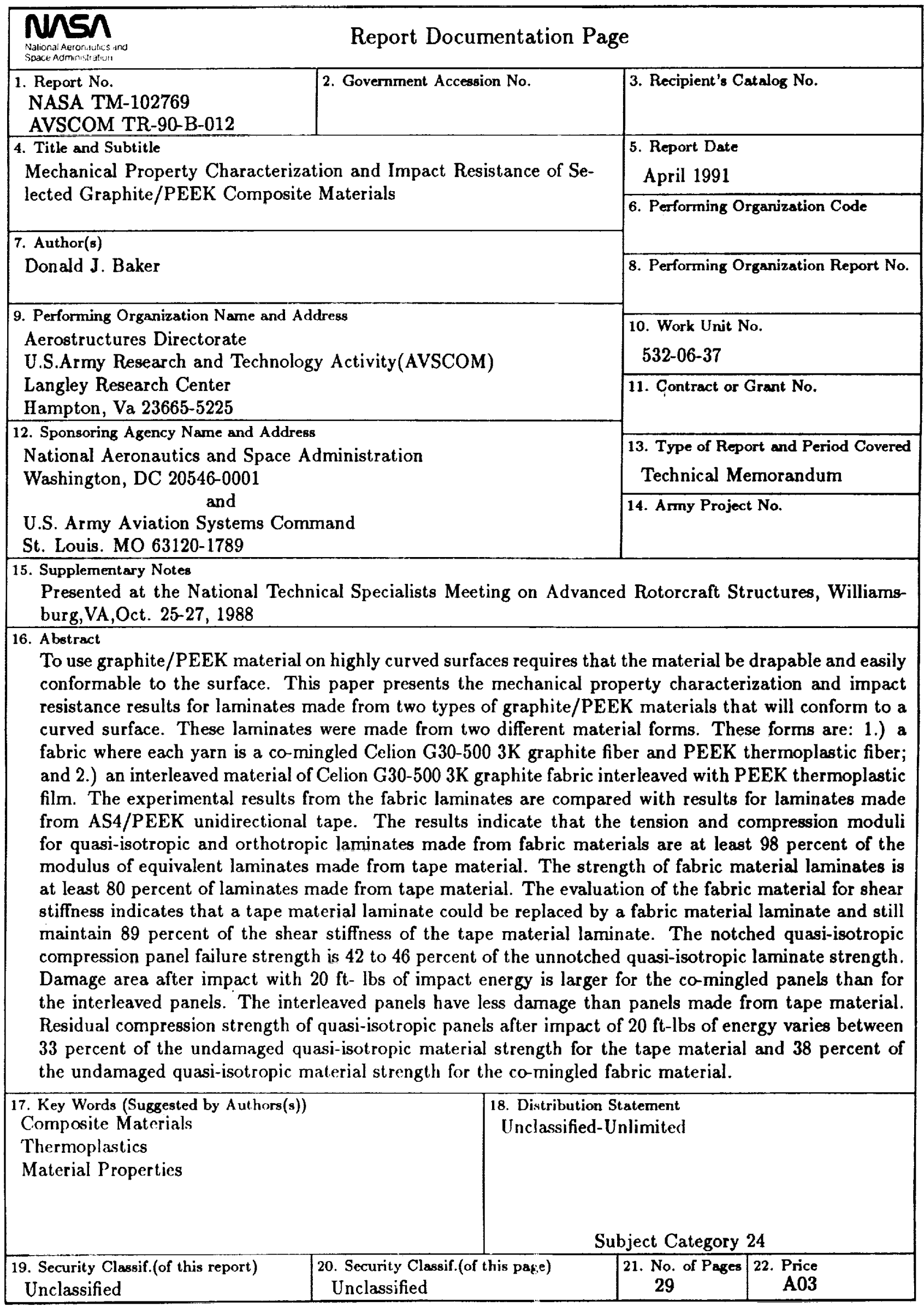

